Discussion

Papers

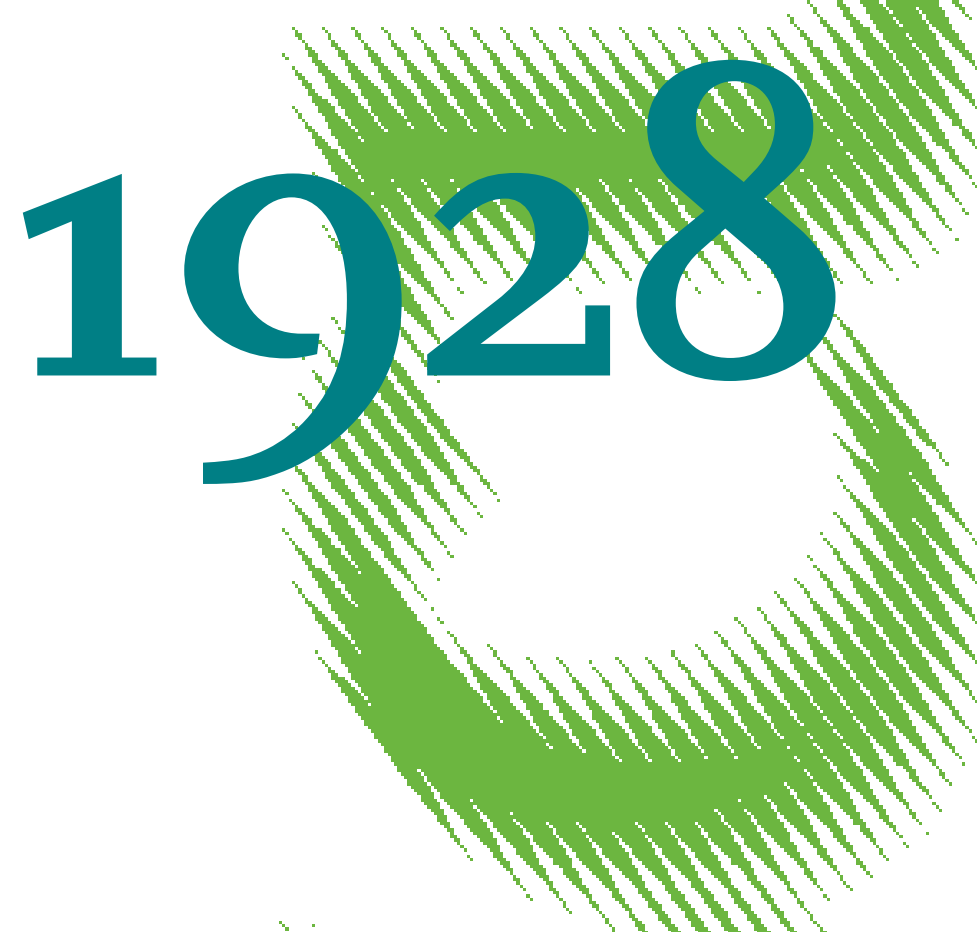

Forward to the Past: Short-Term Effects of the Rent Freeze in Berlin 
Opinions expressed in this paper are those of the author(s) and do not necessarily reflect views of the institute.

IMPRESSUM

(C) DIW Berlin, 2021

DIW Berlin

German Institute for Economic Research

Mohrenstr. 58

10117 Berlin

Tel. +49 (30) $89789-0$

Fax +49 (30) $89789-200$

http://www.diw.de

ISSN electronic edition 1619-4535

Papers can be downloaded free of charge from the DIW Berlin website:

http://www.diw.de/discussionpapers

Discussion Papers of DIW Berlin are indexed in RePEc and SSRN:

http://ideas.repec.org/s/diw/diwwpp.html

http://www.ssrn.com/link/DIW-Berlin-German-Inst-Econ-Res.html 


\title{
Forward to the Past: Short-Term Effects of the Rent Freeze in Berlin
}

\author{
Anja M. Hahn ${ }^{\mathrm{a}}$, Konstantin A. Kholodilin ${ }^{\mathrm{b}, \mathrm{c}}$, Sofie R. Walt ${ }^{\mathrm{a}, \mathrm{d}}$ \\ ${ }^{a}$ Vienna University of Economics and Business, Austria \\ ${ }^{b}$ DIW Berlin, Germany \\ ${ }^{c}$ NRU HSE St. Petersburg, Russia \\ ${ }^{d}$ Luxembourg Institute of Socio-Economic Research, Luxembourg
}

\begin{abstract}
In 2020, Berlin enacted a rigorous rent-control policy: the "Mietendeckel" (rent freeze), aiming to stop rapidly growing rental prices. We evaluate this newly enacted but old-fashionably designed policy by analyzing its immediate supply-side effects. Using a rich pool of rent advertisements reporting asking rents and comprehensive dwelling characteristics, we perform hedonic-style Difference-in-Difference analyses comparing trajectories of dwellings inside and outside the policy's scope. We find no immediate effect upon announcement of the policy. Yet advertised rents drop significantly upon the policy's enactment. Additionally, we document a substitution effect affecting the rental markets of Berlin's (unregulated) satellite city Potsdam and adjacent smaller municipalities. On top, the supplemental quantity analyses reveal a stark reduction of the number of advertised rental units hampering a successful housing search for newcomers, (young) first-time renters and tenants aiming for a different housing opportunity. Keywords: First-Generation Rent Control; Rent Freeze; Urban Policy; Rent Price; Supply Disruptions; Berlin

JEL classification: C14; C43; O18.
\end{abstract}

Acknowledgments and Disclaimer: Our findings were covered by the Austrian newspaper "Die Presse" on 29 November 2020. We further thank Wilfried Altzinger, Claus Michelsen, Margit Schratzenstaller as well as participants at the research seminar at LISER for fruitful comments.

This article uses data kindly provided by Empirica Systeme (www.empirica-systeme.de). The results presented may not reflect the opinion of the data providers. Any remaining errors are ours. Corresponding author: kkholodilin@diw.de. 


\section{Introduction}

Standard economic theory generally argues against rent control due to disturbances in the tenant-unit matching process (Glaeser and Luttmer, 2003). Despite these economic arguments, such policies are ever and again taken advantage of by politicians as soon as housing markets become tight. After decades of relatively moderate rent control, in 2010s housing rents started to rise rapidly and Germany began to expand rent control again. In 2015, the so-called "rent brake" (in German: Mietpreisbremse) was introduced (Mense et al., 2019; Thomschke, 2019) and similar policies were adopted internationally, namely in 2018 in France and in 2020 in Catalonia.

In February 2020, a more radical additional rent control policy came into force in Germany's capital Berlin: the rent freeze (in German: Mietendeckel), a policy responding to soaring rents ${ }^{1}$ by basically switching off fundamental market economy mechanisms.

Unlike typical policies implemented from the 1970s onward, this latest one appears oldfashioned: The rent freeze caps the absolute demanded rent price and may hence be labeled as a first-generation rent control policy in contrast to nowadays' common policies tailored around limiting rent increases (second-generation rent control). The rent freeze is also exceptional in another domain: Ever since 1919, when rent regulations were introduced in Baden and Prussia, it is the first case of a rent control policy in Germany imposed by a state rather than by the federal government.

While the return from rent stabilization to rent freeze is the first one of its kind in the 21 st century, it may not be the last. Its advent attained broad media attention nationally and internationally illustrating how topical Berlin's rent freeze actually is. Politicians, like London's mayor Sadiq Khan, publicly speculated about adopting similar policies.

Berlin's rent freeze determines a maximum rent price per square meter ("valid rent"). To a certain extent, it is allowed to account for usual price-driving attributes such as location and extraordinary provisions. In such cases, strictly pre-defined mark-ups to the basic rent are permitted. Yet, the result is still an unambiguous maximum price. Undercutting this price is

\footnotetext{
${ }^{1}$ Between 2014 and 2018, private households' disposable income in Berlin has increased by about $9.9 \%$ while the customary rent, calculated on the basis of existing and newly concluded rent agreements, has risen by about $15.2 \%$ (see Investitionsbank Berlin, 2020).
} 
allowed, but exceeding can be sanctioned.

This article is the first academic study exploring the immediate effects of this singular policy introduction and provides a broader outlook regarding its potential long-term implications. For this purpose, we specifically select advertised rents to circumvent timing-ambiguity due to the common lengthy time gap between first advertisement and signing of rent contracts. On top, there is usually little bargaining about rents suggesting that asking rents likely reflect the market well (see Waltl, 2018).

We assess both price and volume changes causally linked to the rent freeze. Therefore, we make use of a comprehensive commercial data source: Empirica Systeme that pools several commonly used German online rental marketplaces. The coverage is convincingly representative for all publicly advertised rental objects. On top, we match individual advertisements to administrative data and use media data for supplemental analyses.

We document a remarkable immediate aggregate drop of $7-11 \%$ in advertised rent prices, which we causally link to the rent freeze. While co-movements between sales and rent prices had been rather the norm, the two indices follow opposing trends ever since the rent freeze's enactment, potentially hinting towards a substitution effect between sectors. We document a leakage and likely second substitution effect for Berlin's neighboring city Potsdam as well as for other surrounding municipalities, where asking rents are surging at accelerated pace ever since the rent freeze came into force.

A micro-simulation reveals that advertised rents covered by the rent freeze, to a large extent, do not follow the exact rules established by the new law on how to compute valid rents. We interpret this finding as large-degree non-compliance, although per se only realized rents are restricted but not asking rents. Deviations of asking rents from valid rents were shrinking over time, yet a substantial gap remains. We can only speculate about the reasons leading to this low degree of compliance. A potential explanation could simply be the rather complex computations necessary to identify the valid rent for a specific object. Indeed, it is questionable whether such calculations should be demanded by policy-makers without providing the necessary tools to landlords and renters.

Another gap is insightful: the one between variation among covered and exempt units, respectively. It is larger after announcement and enactment than in the preceding period 
indicating more distinct sub-markets. Thus, monitoring overall rent evolution and affordability seems shortsighted and separate statistics for these sub-markets should become the norm.

Additionally, we document a significant drop in the number of advertised flats for rent in line with findings by Diamond et al. (2019) for San Francisco, where rent control led to a large-scale transformation of previous rental units to owner-occupied ones.

The housing search within the rent segment will hence become particularly challenging for renters-to-be. These include young people who now face a double burden: a low (initial) income and non-availability of suitable housing options. This is problematic given the fact that people aged between 18 and 35 years are the largest group moving into German cities (Kholodilin, 2017b). Similarly, adapting one's housing situation to changes in needs over the life circle can become more difficult and, hence, rather unlikely to regularly happen in the upcoming years. This potentially leads to a lower satisfaction with one's housing conditions.

High rents appear indeed undesirable, yet low housing supply seems at least equally burdensome. Both federal and Berlin's government are investigating ways to extend the supply of newly built dwelling. Nevertheless, in Berlin the results remain meager and can hardly counteract the adverse consequences of the rent freeze. Whether the exemption of new construction from rigorous rent caps will eventually act as strong enough stimulus to fill up the supply holes left by the rent freeze and the insecurities it invoked is to be seen. Either way, shaky times seem to lie ahead for Berlin's housing market. It is, hence, questionable whether the rent freeze eventually leads to an overall net welfare increase or rather decrease.

The remainder of this article is organized as follows: section 2 discusses the rent freeze in an international, historic and regulatory context. Thereafter, section 3 describes the features of the rent freeze policy as well as the timing of related events. Thereafter, section 4 presents the data used in the quantitative assessments of the policy's immediate consequences in section 5. Finally, section 6 conducts a variety of robustness checks and section 7 concludes. A supplemental appendix provides additional details. 


\section{Historic, International, and Regulatory Context}

\subsection{A Visual History of Rent Control in Germany}

In Germany, rent control has a long tradition dating back to 1919 (see Kholodilin, 2017a). Figure 1 depicts the intensity of any kind of rent control measures in Germany between 1910 and 2020, and compares it to the situation in Europe and globally. Regulatory measures were usually put in place in extraordinary times including both world wars (see Kholodilin et al., 2019) and, most recently, in the light of the global economic crisis triggered by the COVID-19 pandemic (see also Francke and Korevaar, 2020). Besides such extreme events, the intensity of rental housing market regulations has been generally increasing over the last years following a decades-long deregulation trend: most notably in Germany yet also more generally in Europe as well as the world in its entirety.

\subsection{National and International Resonance}

Within Germany, the rent freeze attained lots of public attention: Figure 2 plots the number of occurrences of the word Mietendeckel in German media between January 2018 and November 2020. The data are taken from the database GENIOS, ${ }^{2}$ which includes about 2,200 high-quality German-speaking media with the total number of documents exceeding 500 million.

For the first time, the Mietendeckel was mentioned a few times in 2013. However, it is only in early 2019 that the number of occurrences becomes non-negligible. The topic was most prominently discussed between announcement and enactment of the new policy.

Moreover, the example of Berlin inspired people in other parts of Germany and even internationally to request similar regulations in their own cities or municipalities. For instance, in October 2019, Munich's tenants association launched an initiative to organize a referendum concerning the introduction of a similar rent freeze for six years in the German federal state Bavaria. ${ }^{3}$ In September 2020, the mayor of London Sadiq Khan suggested to freeze private housing rents in the British capital for two years alluding to the case of Berlin: "If Berlin can freeze rents for five years, there's no reason London shouldn't be able to freeze rents for two

\footnotetext{
${ }^{2}$ See https://www.genios.de, last accessed in December 2020.

${ }^{3}$ See https://mietenstopp.de, last accessed in December 2020.
} 
Figure 1: Rent Control Regulation Intensity, 1910-2020

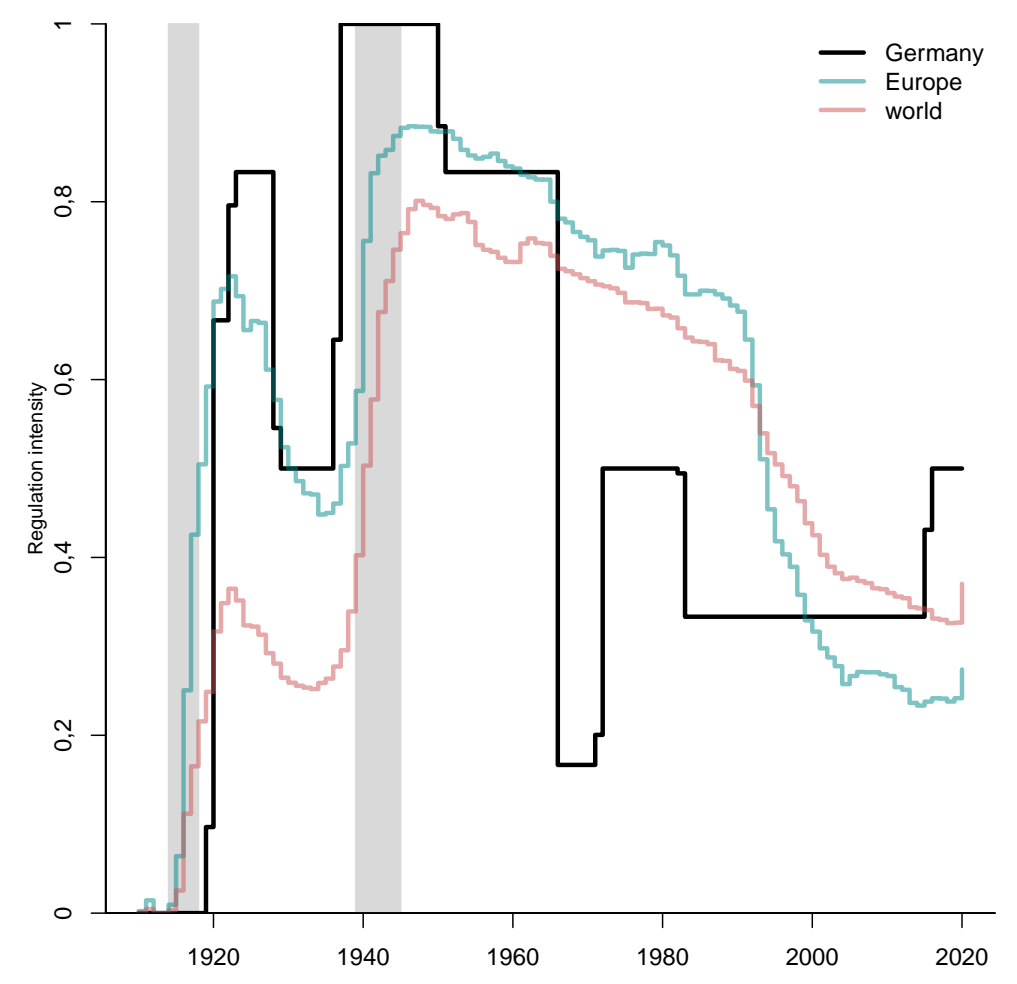

Notes: The figure depicts the intensity of rent control policies in Germany, and compares it to the situation in Europe (40 countries) and the rest of the world (125 countries and sub-national regions). The grey shaded bars indicate World War I and World War II, respectively. The regulation intensity is computed as a simple average of six binary indices, each reflecting an aspect of rent control (e.g., real and nominal freeze, setting of the initial level of rent, and various exceptions).

Source: Own updated calculations are based on Kholodilin (2020).

years in these extraordinary times."

The announcement of the rent freeze in Berlin itself triggered broad international reactions. Leading world newspapers published articles devoted to it: for example, in France ("Berlin gèle les loyers pour stopper leur explosion", by Jean-Michel Hauteville, Le Monde, 7 March 2020); Spain ("Berlín congela los alquileres" by Rosalía Sánchez, ABC, 23 October 2019); and the USA ("Berlin freezes rents for 5 years in a bid to slow gentrification" by Melissa Eddy, The New York Times, 31 January 2020 and "Berlin's property market hit by rent freeze and viral lockdown" by Layli Foroudi, Financial Times, 10 April 2020).

\footnotetext{
${ }^{4}$ See https://www. london.gov.uk/press-releases/mayoral/mayor-calls-for-two-year-rent-freeze, last accessed in December 2020.
} 
Figure 2: Occurrences of the word Mietendeckel in German media, 2018-2020

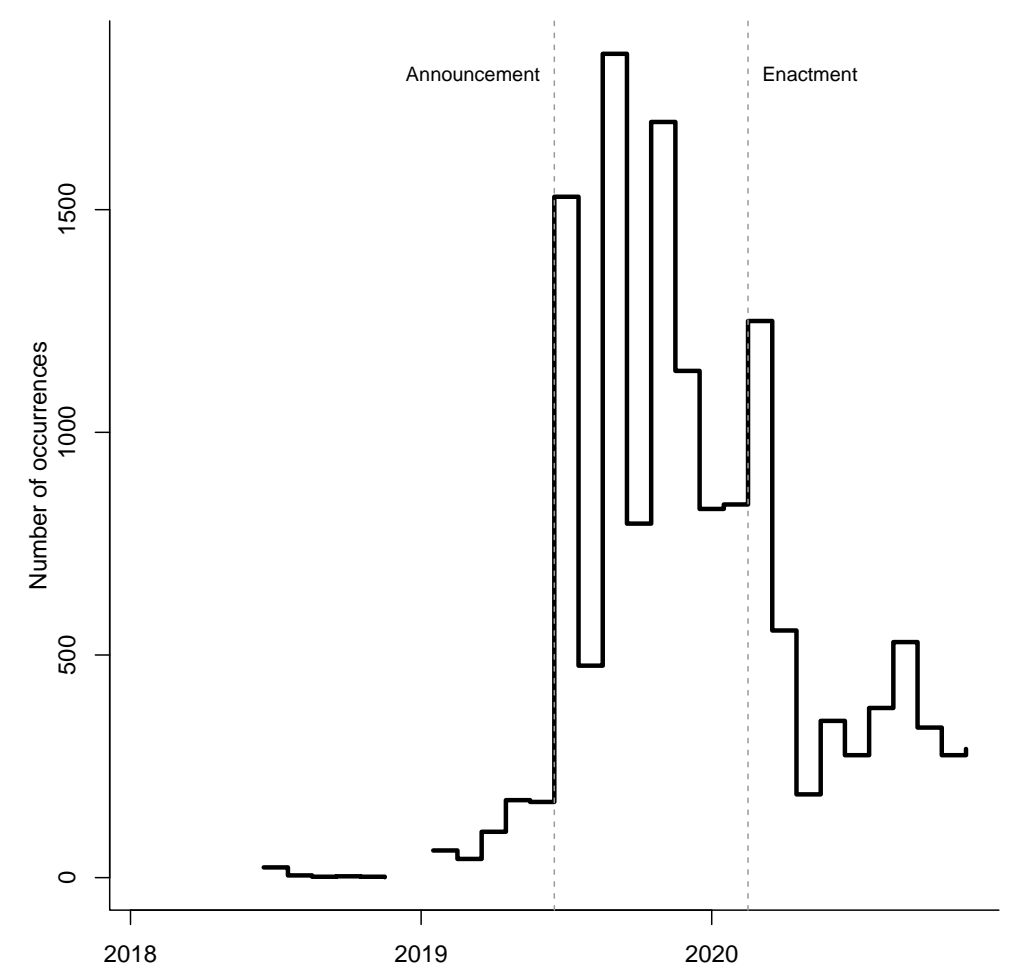

Notes: The figure shows the monthly number of occurrences of the word Mietendeckel in the database of German print media GENIOS. The data are obtained through an automatic search for this keyword in the GENIOS database across all media items published between January 2000 and November 2020.

Source: GENIOS and own representation.

\subsection{Regulatory Context}

For Berlin's inhabitants, there are currently two types of fostering policies available that could, at least in part, compensate for the decreases in housing affordability ${ }^{5}$ due to surging rents: social housing construction (sozialer Wohnungsbau) and housing allowances (Wohngeld).

The former covers subsidized private or directly publicly initiated construction of affordable housing units. Rents are substantially lower than regular market rents, yet tenants need to fulfill certain criteria (mainly related to income) to be eligible. Housing allowances are directly paid to tenants whenever their household income falls short of a certain minimum depending on the number and age of household members . Germany-wide social housing makes up just

\footnotetext{
${ }^{5}$ See Table 16 for related demographic statistics per district.
} 
about $4 \%$ of the total housing stock (Housing Europe, 2017) and, despite recently adopted measures, ${ }^{6}$ the situation is likely to not change to any substantial extent in the near future. The housing allowance system too recently has been reformed leading to an increase in the allowances' amount and, more importantly, to a creation of a built-in indexation mechanism. The latter links the amount granted to the nationwide official rent price index. ${ }^{7}$

\section{Policy Features}

\subsection{The Rent Brake}

The new rent freeze regulation was preceded by the so-called rent brake that was introduced in June 2015. ${ }^{8}$ The rent for a dwelling located in an area classified as a tight housing market (angespannter Wohnungsmarkt) may be at most 10\% higher than the typical local rent. Thus, the rent brake is a strict form of the second-generation rent control: unlike a standard version, which allows setting of initial rent at the market level, the rent brake imposes limitations on this initial rent. Each of the 16 German federal states is empowered to establish the areas with tight housing market, which are subsequently subject to the rent brake regulations for a period of at most five years. By 2020, 12 out of 16 German federal states have adopted the rent brake.

These areas can be individual municipalities or any well-specified part thereof. In practice, however, usually an entire municipality is declared as such an area.

To identify a tight market, at least one of the following four conditions must be met: (1) local rents grow faster than at the national level; (2) the local average rent-to-income ratio is significantly higher than the national average; (3) population grows, whereas new housing construction does not create enough dwellings; or (4) the vacancy rate is low, while demand is high.

Nonetheless, even in areas witnessing tight housing market conditions following the above definition not all dwellings are subject to the rent brake. There are two explicit exceptions:

\footnotetext{
${ }^{6}$ For example in 2015, the federal support towards the annual social housing construction budget was increased from 518.2 to 1,018.2 million EUR. ("Asylverfahrensbeschleunigungsgesetz" as of 20 October 2015, BGBl. I S. 1722; enacted on 24 October 2015).

7"Gesetz zur Stärkung des Wohngeldes" as of 30 November 2019, BGBl. I S. 1877 (Nr. 44); enacted on 1 January 2020.

${ }^{8}$ The title of the original law is "Gesetz zur Dämpfung des Mietanstiegs auf angespannten Wohnungsmärkten und zur Stärkung des Bestellerprinzips bei der Wohnungsvermittlung (MietNovG)" as of 21 April 2015. See the "Bundesgesetzblatt Jahrgang 2015 Teil I Nr. 16, ausgegeben zu Bonn am 27. April 2015" for juridical details.
} 
(1) dwellings used and let for the first time since 1 October 2014; or (2) dwellings let for the first time after an extensive modernization. Though initially set for five years, the law was prolonged for another five years in March 2020. ${ }^{9}$

\subsection{The Rent Freeze}

The idea of a rent freeze was publicly announced on 4 June 2019 by Berlin's then-minister of construction Katrin Lompscher (a member of the leftist political party Die Linke). ${ }^{10}$ As an immediate reaction, on 9 June 2019, the landlords' and homeowners' association Haus und Grund called upon landlords to raise rents before 18 June 2019. By that, the basic rent determining the basis for rent setting for years to come would rise. ${ }^{11}$ Initially, it was unclear, whether the controversial law would indeed be enacted, since the constitutional basis for lawmaking in the domain of housing markets at the state level was (and remains) shaky. However, in late 2019 it became clear that the law will come and, in February 2020, Berlin eventually indeed enacted the pre-announced rent freeze. ${ }^{12}$

So what are the main features of the law? First, it extends only to Berlin and should be valid during five years after its publication. Second, it covers all residential premises with several exceptions laid out below. Third, rents (exclusive running costs) are frozen at the 18 June 2019 level. Exceptions include most importantly ${ }^{13}$ housing units that became ready for occupation for the first time on 1 January 2014 or later, residential premises that were uninhabitable (and indeed vacant) for an extended period of time, or were remodelled with efforts comparably to new construction and hence are new to the rental market.

On top, the law defines the so-called valid rent (zulässige Miete) to range between 3.92

\footnotetext{
${ }^{9}$ The title of the proposed law is "Gesetz zur Verlängerung und Verbesserung der Regelungen über die zulässige Miethöhe bei Mietbeginn" as of 19 March 2020.

${ }^{10}$ Information der Koalition zu einem Berliner Mietengesetz Eckpunkte für ein Berliner Mietengesetz; https : //haus-und-grund-berlin.de/wp-content/uploads/2019/06/Eckpunkte_Berliner_Mietengesetz.pdf, last accessed in December 2020.

11"Erhöhen Sie bis zum 17. Juni 2019 die Miete!" https://haus-und-grund-berlin.de/ wichtig-erhoehen-sie-vor-dem-18-juni-2019-die-miete/, last accessed in December 2020.

${ }^{12}$ The title of the original law is "Gesetz zur Mietenbegrenzung im Wohnungswesen in Berlin (MietenWoG Bln)" as of 11 February 2020. The law was enacted on 23 February 2020.

${ }^{13}$ Further premises excluded from the regulation's scope are units fulfilling at least one of the following criteria: (1) housing units built under state support schemes; (2) residential premises modernized and refurbished using public aid and which are already subject to rent restrictions; (3) dormitories and similar accommodation facilities.
} 
and 9.80 EUR $/ \mathrm{m}^{2}$ per month. The exact amount depends on the building's construction year and equipment (heating and bath). The exact amounts and requirements are summarized in Table 1.

Table 1: Valid Rent under the Rent Freeze

\begin{tabular}{|c|c|c|c|c|c|}
\hline & & \multicolumn{3}{|c|}{ Equipment } & \multirow{2}{*}{$\begin{array}{l}\text { Valid Rent } \\
{\left[\mathrm{EUR} / \mathrm{m}^{2}\right]}\end{array}$} \\
\hline & & $C H \wedge B$ & $C H \vee B$ & $\neg C H \wedge \neg B$ & \\
\hline 1. & before 1918 & $\checkmark$ & & & 6.45 \\
\hline 2. & & & $\checkmark$ & & 5.00 \\
\hline 3. & & & & $\checkmark$ & 3.92 \\
\hline 4. & $1919-1949$ & $\checkmark$ & & & 6.27 \\
\hline 5. & & & $\checkmark$ & & 5.22 \\
\hline 6. & & & & $\checkmark$ & 4.59 \\
\hline 7. & $1950-1964$ & $\checkmark$ & & & 6.08 \\
\hline 8. & & & $\checkmark$ & & 5.62 \\
\hline 9. & $1965-1972$ & $\checkmark$ & & & 5.95 \\
\hline 10. & $1973-1990$ & $\checkmark$ & & & 6.04 \\
\hline 11. & $1991-2002$ & $\checkmark$ & & & 8.13 \\
\hline 12. & $2003-2013$ & $\checkmark$ & & & 9.80 \\
\hline
\end{tabular}

Notes: The table reports the (unadjusted) valid rent per square meter depending on the year of first-time availability for rent and the provision of basic equipment $(C H \wedge B$ central heating and bathroom, $C H \vee B$ central heating or bathroom, $\neg C H \wedge \neg B$ neither central heating nor bathroom).

Source: "Gesetz zur Mietenbegrenzung im Wohnungswesen in Berlin (MietenWoG Bln)", §6, as of 11 February 2020.

A somewhat higher rent is allowed for dwellings in two-family houses $(+10 \%)$ or dwellings with modern equipment $\left(+1 \mathrm{EUR} / \mathrm{m}^{2}\right)$. Modern equipment (moderne Ausstattung) means that at least three of the following features are available: an elevator (accessible without steps), fitted kitchen, valuable sanitary equipment, valuable flooring in most rooms, or energy consumption below $120 \mathrm{kWh} / \mathrm{m}^{2}$. In addition, the location ${ }^{14}$ is factored in when assessing excessive rent: $-0.28 \mathrm{EUR} / \mathrm{m}^{2}$ for simple locations (einfache Wohnlage), $-0.09 \mathrm{EUR} / \mathrm{m}^{2}$ for average locations (mittlere Wohnlage), and $+0.74 \mathrm{EUR} / \mathrm{m}^{2}$ for good locations (gute Wohnlage).

\footnotetext{
${ }^{14}$ See therefore the official classification of locations in Berlin ("Mietspiegel"): https://www. stadtentwicklung.berlin.de/wohnen/mietspiegel/de/wohnlagenkarte.shtml, last accessed in December 2020 .
} 
Hence, at most the valid rent could be $11.54 \mathrm{EUR} / \mathrm{m}^{2}$ corresponding to a house built between 2003 and 2013, having central heating and a bathroom as well as general modern equipment, and located in a good neighborhood.

It may well be the case that the actually paid rent in June 2019 exceeds the valid rent. Such an excessive rent (überhöhte Miete) is defined as one exceeding the valid rent by more than 20\%. Such a rent must be reduced to reach the maximal allowed level. Non-compliance is classified as an administrative offense and may lead to substantial fines up to EUR 500,000.

The rent can only be increased starting from 1 January 2022 and the rate of increase is limited by the growth rate of the Germany-wide consumer price index subject to a general cap of $1.3 \%$. However, such rent increases are only allowed, if the current one falls short the valid rent. Thus, rents equal to or exceeding the valid rent are effectively frozen. Finally, rent increases are permitted in case of modernization, yet in this case the allowed monthly rent may be increased by no more than $1 \mathrm{EUR} / \mathrm{m}^{2}$ and the resulting rent has, again, follow the general guidelines.

\subsection{Rent Brake versus Rent Freeze}

The valid rents set, according to the rent freeze, as a rule, appears to be lower than those following the rent brake guidelines. The horizontal axis in Figure 3 corresponds to the valid rent

prices set by the rent freeze, while the vertical axis depicts the valid rental prices according to the 2019 Mietspiegel. The latter is an official summary of market-based rent price information and serves as the basis for setting initial rents, according to the rent brake.

The colors denote different floor areas of dwellings, whereas the dots' shape corresponds to the year of completion of the buildings. Rents refer to dwellings located in average zones. Therefore, we subtract 0.09 EUR to obtain rents following the rent freeze rules.

In the Mietspiegel table, there are different rents specified for East and West Berlin for completion years between 1973 and 1990. The rent freeze does not comprise such distinctions. Therefore, we computed a simple average of the East and West Berlin's rental prices. In addition, rent freeze does not distinguish between different dwelling sizes.

As seen, most points in Figure 3 lie above the $45^{\circ}$-line implying that the rent brake prices are predominantly higher than those according to the rent freeze. We observe particularly large deviations between rent brake and rent freeze prices for small dwellings (40 $\mathrm{m}^{2}$ and smaller). 


\section{Figure 3: Valid Rent: Rent Freeze vs. Rent Brake}

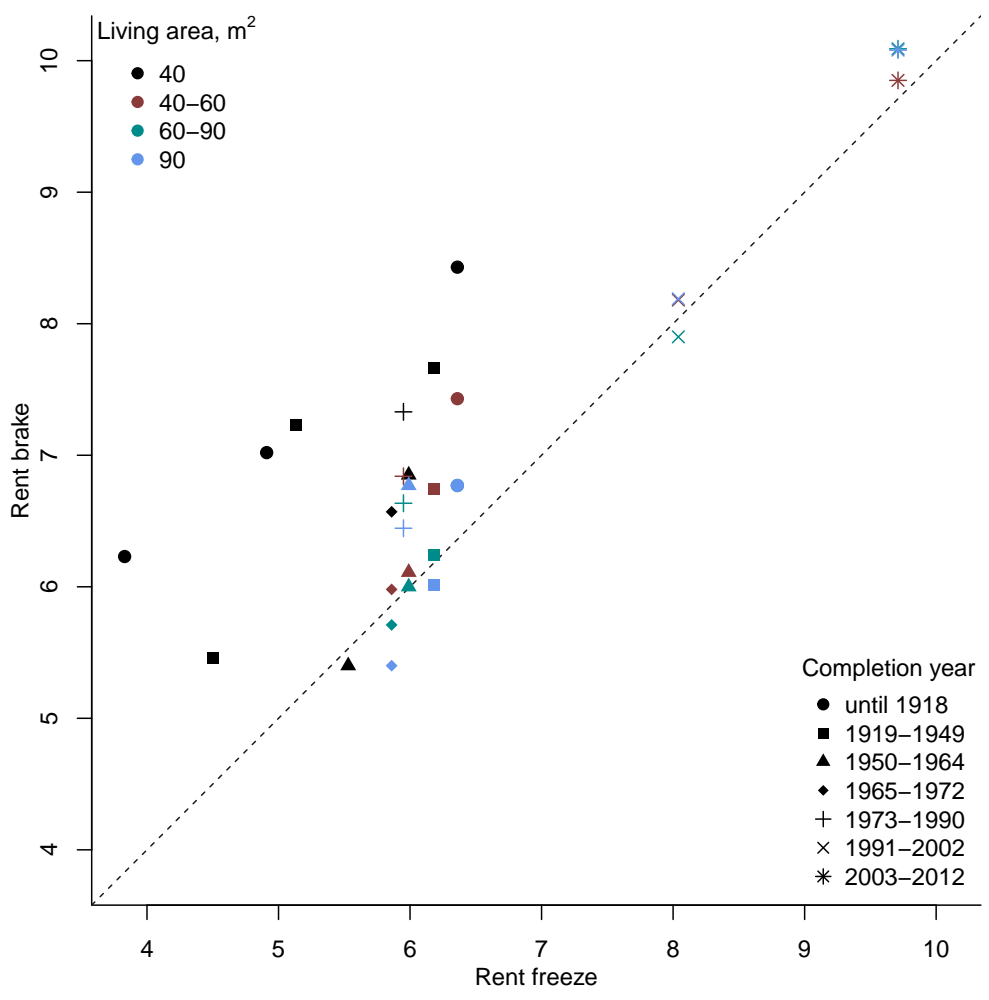

Notes: The figure shows the valid rental prices per $\mathrm{m}^{2}$ per month, according to the rent freeze law (horizontal axis) and rent brake law as contained in the Mietspiegel of 2019 (vertical axis). The diagonal dotted line has a slope of $45^{\circ}$ and, thus, shows the points where the values of both rent freeze and rent brake coincide.

Sources: (1) Mietendeckel - "Gesetz zur Mietenbegrenzung im Wohnungswesen in Berlin (MietenWoG Bln)" as of 11 February 2020; (2) Mietspiegel of 2019 - Senatsverwaltung für Stadtentwicklung und Wohnen, https://www.stadtentwicklung.berlin.de/ wohnen/mietspiegel/de/downloads.shtml; and (3) own representation.

Interestingly, the rents for buildings completed prior to 1919 and after 1990 are higher than those for buildings completed between 1919 and 1990. The lowest rents per square meter are set for the dwellings in buildings completed between 1965 and 1972. Moreover, for older dwellings, the rent per square meter is higher for smaller dwellings, while we do not detect such a monotonicity for dwellings completed after 1990 .

All in all, the prices set under the rent freeze law lag behind even after already too low rental prices set under the rent brake regulation. However, this difference will disappear, if we compute the excessive rent threshold: $10 \%$ above the valid rental price for the rent brake and $20 \%$ for the rent freeze. 


\section{Data}

We assess the immediate impact of the policies on advertised asking rents. For this purpose, we use online sale and rent advertisements collected and processed by Empirica Systeme. ${ }^{15}$ The platform gathers ample information on all types of apartments and houses on the market by pooling a rich set of real estate information providers. Also, it includes various dwelling characteristics and, importantly, precise information on location obtained by geo-coding exact addresses mentioned in the ads. ${ }^{16}$

We exclude statistical outliers (properties older than 300 years) from our estimation sample as well as not yet build but already advertised units. In total, we exclude eight observations leaving 74,657 in the full estimation sample.

Table 2: Summary Statistics

\begin{tabular}{lccccccc}
\hline \hline & & & & & & \\
& Mean & St. Dev. & Minimun & Pctl(25) & Median & Pctl(75) & Maximun \\
\hline Monthly Rent [EUR] & 733.06 & 459.20 & 65.00 & 448.90 & 600.00 & 870.00 & $11,000.00$ \\
Monthly Rent [EUR/m ${ }^{2}$ ] & 10.71 & 3.72 & 2.37 & 8.01 & 10.00 & 12.57 & 49.38 \\
Age [Years] & 63.97 & 40.05 & 0.00 & 32.00 & 57.00 & 107.00 & 265.00 \\
Living Area [m ${ }^{2}$ ] & 67.20 & 27.85 & 10.00 & 50.00 & 62.20 & 78.00 & 416.00 \\
\hline & & 1 Room & 2 Rooms & 3 Rooms & 4 Rooms & $4+$ Rooms \\
Number of Rooms [\%] & 19.61 & 44.87 & 25.89 & 7.76 & 1.86 & \\
\hline Shares [\%] & Yes & No & & & & \\
First Time Occupation & & 18.00 & 82.00 & & & & \\
Garden & 13.20 & 86.80 & & & & \\
Balcony/Terrace & 73.32 & 26.68 & & & & \\
Fitted Kitchen & 41.23 & 58.77 & & & & \\
Parking & 18.73 & 81.27 & & & & \\
Elevator & 46.87 & 53.13 & & & & \\
Separate Toilet & 10.40 & 89.60 & & & & \\
\hline
\end{tabular}

Number of observations

74,657

Notes: The table reports summary statistics of flats offered for rent in the period between 1 January 2018 and 30 June 2020. All advertisements also include geo-coded information of the location of the unit (longitudes and latitudes). Statistical outliers and observations missing exact addresses are removed.

\footnotetext{
${ }^{15}$ See https://www.empirica-systeme.de (last accessed in December 2020) and a description of sources as well as quality checks applied.

${ }^{16}$ In the case of missing exact address information (e.g., street name but no street number), geographic coordinates are estimated as well as a "confidence circle". We perform a robustness check where we include also these observations (see section 6).
} 
Table 2 reports summary statistics compiled from all advertisements included into our estimation sample. More detailed statistics are compiled to assess the comparability of types of flats advertised before and after the announcement and enactment of the policy, respectively. These detailed breakdowns are reported as a part of comprehensive robustness and plausibility checks in section 6 .

\section{Empirical strategy}

\subsection{Aggregate Price Effects Measured by Indices}

To illustrate the general trends in Berlin's housing market, Figure 4 shows hedonic rent price indices (see Rosen, 1974). We construct both a time-continuous (see Waltl, 2016) used to pin down the exact timing of price effects and, as benchmark, a standard monthly time-dummy rent index (see de Haan and Diewert, 2013).

To put movements into perspective, we also show a residential house price index based on advertised sales prices (separate indices for regulated and non-regulated units are shown in Figure 9 in the appendix). Since roughly mid-2018, sales prices were increasing at a much more rapid pace than rents. Sales prices, though being more volatile, also left an ever-increasing price trajectory, yet no declining prices are observed. While co-movements between sales and rent prices were rather the norm before 2019, ever since the rent freeze's enactment the two indices follow opposing trends.

We identify increases in rent prices up until June 2019 before asking rents first stagnate and subsequently started to fall. We show in subsection 5.2 that immediate movements around the announcement date are not statistically significantly driven by apartments covered by the rent freeze but may rather reflect generally increased insecurity. In contrast, the continuing decline in rents ever since February 2020 already hints towards substantial price effects related to the rent freeze.

The exceptional disruptions in Berlin's rental market are even more visible when comparing changes in asking rents in Berlin to those in other major German cities as well as Berlin's satellite city Potsdam and adjacent municipalities (see Figure 5 and Table 3).

While asking rents kept increasing in 2020 at a similar pace in all other cities, asking rents in Berlin fell. The adjacent areas as well as the satellite city Potsdam are - though part of 


\section{Figure 4: Nominal Sales and Rent Price Indices: Berlin}

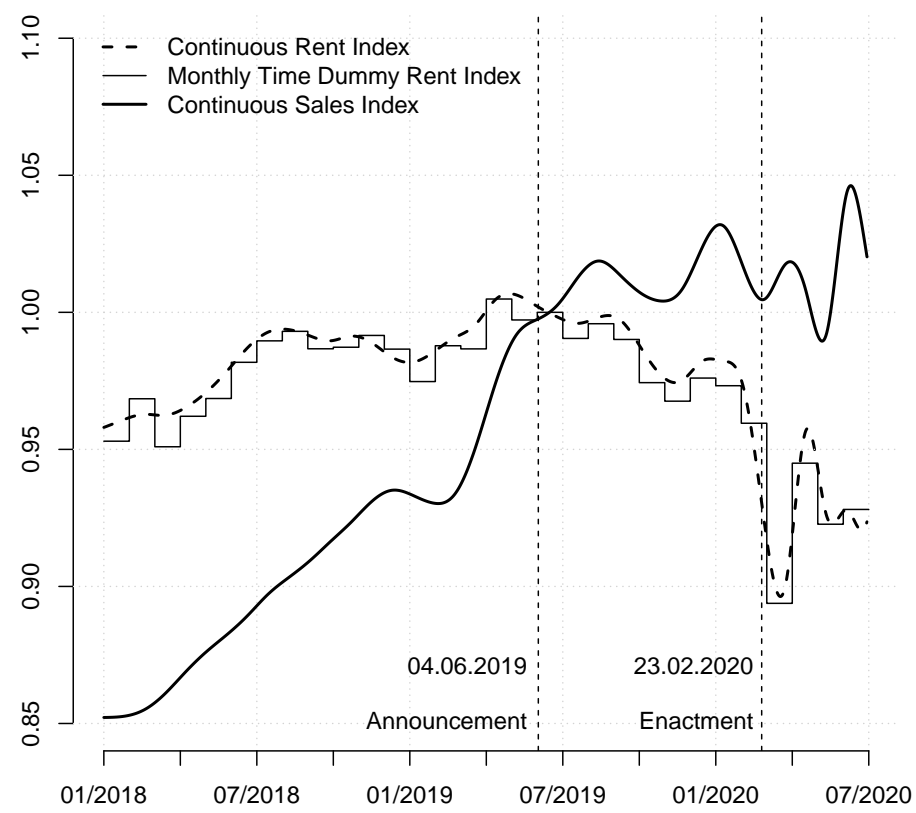

Notes: The indices unveil the general trend in the sales and rental market between 2018 and the end of the second quarter 2020 . Indices are normalized to their respective average index number in June 2019, when the announcement took place. The timecontinuous indices follow the methodology developed in Waltl (2016) based on adaptive smoothing techniques. The continuous trend in the rental market is compared to a standard monthly time-dummy index (see de Haan and Diewert, 2013).

the urban conglomerate - not covered by the rent freeze as they are located outside of the administrative boundaries of the German capital.

Particularly remarkable is the sharp rise in rents in Potsdam as reported in Table 3. The cumulative change ever since the rent freeze's announcement amounts to roughly $5 \%, 9 \%$, and $12 \%$ in the first three quarters of 2020, correspondingly. Comparing these increases to Germanywide changes or other major cities, Berlin truly stands out. Smaller adjacent municipalities too experienced substantial increases comparable to that in Potsdam. These findings indicate a substitution effect very likely triggered by the rent freeze, which exclusively applies to dwellings strictly located within Berlin's administrative boundaries. 
Figure 5: Rent Price Indices for Selected German Cities and Communes

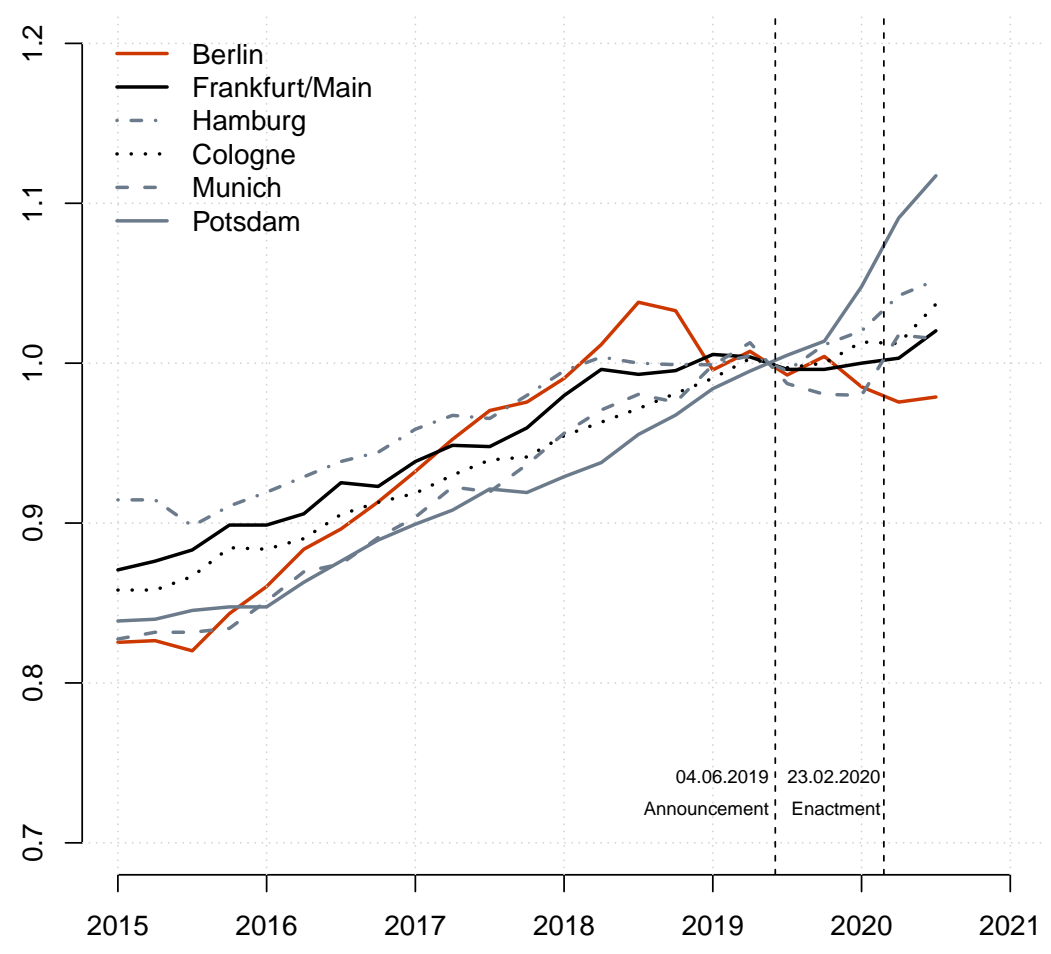

Notes: The figure shows quarterly asking rent price indices for existing flats ("Bestandswohnungen") for several large German cities (Cologne, Frankfurt/Main, Hamburg, and Munich) as well as for Berlin's satellite city Potsdam. Indices are normalized to the average index number in the second and third quarters 2019.

Source: Empirica Systeme.

\subsection{Identification Strategy}

We use the rent freeze's announcement date and enactment date for causally identifying corresponding supply-side reactions. We specifically select advertised rents for this purpose to avoid timing ambiguity due to the common lengthy time gap between first advertisement and signing of rent contracts. The rent freeze was first communicated on 4 June 2019 and, finally, became effective on 23 February 2020. These two dates delineate the three clearly distinguishable time periods as depicted in Figure 6.

To put a clear focus on the immediate effects, we look at the shorter periods of 28 days 


\section{Table 3: Berlin vs. Other German Locations}

\begin{tabular}{lcccc}
\hline \hline & & \multicolumn{2}{c}{ Change since Announcement $-\Delta$} \\
\cline { 2 - 4 } Germany & Aggregation Level & Q1:2020 & Q2:2020 & Q3:2020 \\
\cline { 2 - 4 } Berlin & Whole Country & 0.019 & 0.028 & 0.035 \\
\cline { 2 - 5 } Hamburg & Major City & -0.015 & -0.024 & -0.021 \\
Cologne & Major City & 0.020 & 0.042 & 0.052 \\
Frankfurt/Main & Major City & 0.013 & 0.012 & 0.037 \\
Munich & Major City & 0.000 & 0.003 & 0.020 \\
Potsdam & Major City & -0.020 & 0.018 & 0.015 \\
Barnim & Satellite City & 0.048 & 0.091 & 0.117 \\
Dahme-Spreewald & Adjacent Municipality & 0.023 & 0.053 & 0.084 \\
Havelland & Adjacent Municipality & 0.028 & 0.060 & 0.081 \\
Märkisch-Oderland & Adjacent Municipality & 0.015 & 0.017 & 0.055 \\
Oberhavel & Adjacent Municipality & 0.075 & 0.067 & 0.090 \\
Oder-Spree & Adjacent Municipality & 0.027 & 0.039 & 0.075 \\
Potsdam-Mittelmark & Adjacent Municipality & 0.012 & 0.011 & 0.034 \\
\hline \hline
\end{tabular}

Notes: The table reports changes in various hedonic rent price indices. Nearby municipalities are adjacent municipalities bordering Berlin. $I\left(Q_{t}\right)$, the change in index numbers between quarter $Q_{t}$ and the reference period, is computed via $\Delta\left(Q_{t}\right)=$ $I\left(Q_{t}\right) /$ Mean $(I(\mathrm{Q} 2: 2019), I(\mathrm{Q} 3: 2019))-1$.

Source: Author's calculations based on indices provided by Empirica Systeme.

before and after each event. The length of 28 days has been chosen in an attempt to exclude possibly confounding effects of the COVID-19 pandemic: on 22 March 2020, i.e., 28 days after the enactment, the second regulation on pandemic containment measures ${ }^{17}$ became effective in Berlin and along with this came the prohibition of gatherings of more than ten people, the closing down of restaurants, and the required minimum distance of 1.5 meters between people not belonging to the same households. The strict sanitary measures aimed at combating the pandemic led to a deep economic crisis that could have affected housing prices.

The resulting sub-periods are: (1) pre-announcement, Pre-A - between 7 May 2019 and 3 June 2019; (2) post-announcement, Post-A - between 4 June 2019 and 1 July 2019, i.e., after

\footnotetext{
${ }^{17}$ See "Zweite Verordnung zur Änderung der SARS-CoV-2-Eindämmungsmaßnahmenverordnung, vom 21. März 2020", available online in German https://www.berlin.de/sen/justiz/service/ gesetze-und-verordnungen/2020/ausgabe-nr-12-vom-27-3-2020-s-217-224.pdf, last accessed in December 2020
} 


\section{Figure 6: Time-line}

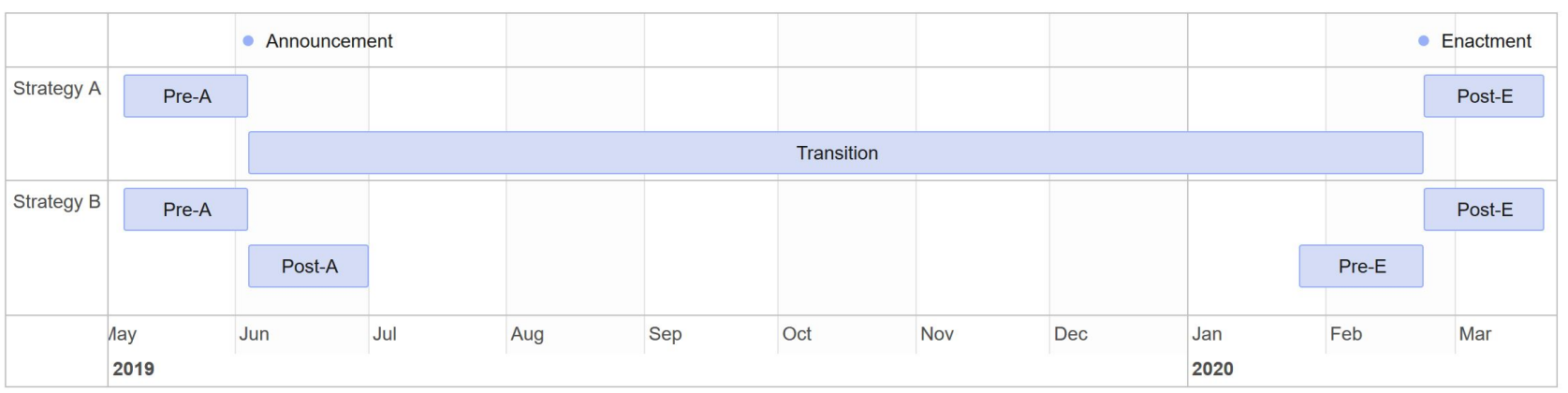

Notes: The timelines visualizes the sequence of relevant events as well as the definition of periods.

the announcement of the new law; (3) pre-enactment, Pre-E - between 26 January 2020 and 22 February 2020; and (4) post-enactment, Post-E - between 23 February 2020 and 21 March 2020, i.e., after the rent freeze became legally binding.

We estimate hedonic difference in differences (DiD) models in order to identify the immediate effects upon announcement and enactment of the rent freeze. Therefore, we use dwellings explicitly excluded from the policy as control group. As a robustness check, subsection 6.1 relaxes the very strict selection criteria to advertised units that are not for sure yet likely being exempt.

The explicit control group comprises newly constructed buildings ready for occupancy for the first time starting from 1 January 2014 or, in particular cases, apartments that have to a substantial degree been modernized (Neubauaufwand) after a prolonged period of non-occupancy. To identify those objects, we use the variable "first time occupancy" collected by Empirica Systeme. This yields a subset comprising all apartments that were ready for first time occupancy starting from 1 January 2014, covering both flats in newly built houses and substantially refurbished flats. Moreover, apartments built starting from 1 January 2014 generally enter the control group as they are not covered by the rent freeze.

To increase precision, we exclude relatively old flats from the control group, which nevertheless are offered under the label "first-time occupancy", even though they have not undergone any modernization. In their investigation regarding the rent brake, Mense et al. (2019) exclude dwellings with building ages ranging between two and ten years, although they were reported as first time use, in order to mitigate measurement error. We follow this approach and exclude 
flats built before 2013 yet still advertised for first time occupancy. In line with that, we remove all renovated units where the year of modernization lies in the more distant past, i.e., dwellings that were renovated before 2013 .

One could be concerned that dwellings in the control and treatment group are quite different and may attract a distinct audience. We tackle this issue by including a rich and established set of hedonic control variables and, most importantly, the exact location of a dwelling. In this spirit, we check the common trend assumption. Figure 9 in Appendix shows trends for both the treatment and control group by comparing carefully compiled hedonic indices and, indeed, they seem to follow a common trend up until the announcement of the new law.

We rely on two strategies as depicted in Figure 6. Strategy $A$ relies on a single model covering the entire time span (see model A), whereas strategy $B$ estimates separate models for the events "announcement" (model B.1) and "enactment" (model B.2):

$$
\begin{aligned}
\log \left(R_{i t}\right)= & \beta_{0}+\beta_{1} C_{i}+\beta_{3} \text { Transition }_{t}+\beta_{4} \text { Post-E }_{t} \\
& +\beta_{6} C_{i} \times \text { Transition }_{t}+\beta_{7} C_{i} \times \text { Post-E }_{t}+\gamma^{\prime} X_{i}+\varepsilon_{i t}, \\
\log \left(R_{i t}\right)= & \beta_{0}+\beta_{1} C_{i}+\beta_{2} \text { Post- }_{t}+\beta_{5} C_{i} \times \text { Post-A }_{t}+\gamma^{\prime} X_{i}+\varepsilon_{i t}, \\
\log \left(R_{i t}\right)= & \beta_{0}+\beta_{1} C_{i}+\beta_{4} \text { Post- }_{t}+\beta_{7} C_{i} \times \text { Post- }_{t}+\gamma^{\prime} X_{i}+\varepsilon_{i t},
\end{aligned}
$$

where $R_{i t}$ denotes the monthly rent of flat $i$ at time $t$. The dummy variable $C_{i}$ equals one, if the apartment is covered by the rent freeze, and zero otherwise. The dummies Transition ${ }_{t}$, Pre- $_{t}$,

Post- $\mathrm{A}_{t}$, and Post- $\mathrm{E}_{t}$ indicate in which time period the ad was observed. $\beta_{j}$ for $j \in\{0, \ldots, 7\}$ are associated parameters. $X_{i}$ denotes a matrix containing various hedonic flat characteristics including a smooth locational spline with associated parameter vector $\gamma$. Finally, $\varepsilon_{i t}$ is a normally and independently distributed error term. Models are estimated via penalized least squares.

\subsection{Price Effects}

Table 4 reports key estimation results focusing on the 28-days periods before the rent freeze's announcement and its legally-binding enactment, as well as the in-between transition period as described in Figure 6. Table 11 in Appendix reports the full set of results. 
Units covered by the rent freeze (treatment group) are generally less expensive than those exempt from it (control group). Given the fact that the control group comprises new and renovated flats, this result follows expectations. Reassuringly, the size of effect associated with the classification into treatment and control group remains practically identical for both specifications.

The mere announcement has no significant immediate impact on advertised rents when contrasting the regulated sector against the unregulated one. Hence, owners did not follow the call by the landlords' and homeowners' association Haus und Grund to raise rents before the rent freeze would come into force. ${ }^{18}$

In contrast, legal enactment of the rent freeze led to a sharp and statistically strongly significant decrease in asking rents among the treatment group $\left(-0.075^{* * *}\right)$ as compared to the non-regulated control group.

However, the effect sizes we estimate potentially depend on the - possibly adverse - changes in demanded rents for unregulated ones. Although we cannot entirely rule out the existence of such counter-effects, our study design limits such impacts: First, we look at the very short-run. Systematic effects may - if ever - only be observed later on. Second, occupied dwellings simply cannot be freed up immediately due to contractually agreed contract lengths and notice periods. The time elapsed between the first concrete and detailed announcement, and final enactment is likely too short to trigger coherent adverse reactions.

\subsection{Volume Effects}

Next to price effects, the announcement and enactment of restrictive policies may well affect the number of posted advertisements ("volume") which measures quantity effects on the supply side. Diamond et al. (2019), for instance, find that the introduction of rent control policies limited renters' mobility in San Francisco. On top "[l]andlords treated by rent control reduce rental housing supplies by 15 percent by selling to owner-occupants and redeveloping buildings." From a macroeconomic perspective, Leamer (2007) even argues in favor of assessing the housing volume cycle rather than focusing on price movements only.

\footnotetext{
${ }^{18}$ It is still possible that the rents were raised for the already concluded contracts, which cannot be observed from the asking prices. However, given rather strict regulations concerning the rent adjustment within existing contracts, this is quite improbable.
} 


\section{Table 4: Main Results}

\begin{tabular}{lccc}
\hline \hline & \multicolumn{2}{c}{ Response: Monthly Rent (log) } \\
\cline { 2 - 4 } & Strategy A & \multicolumn{2}{c}{ Strategy B } \\
\cline { 2 - 4 } Treatment & $-0.063^{* * *}$ & $-0.075^{* * *}$ & $-0.073^{* *}$ \\
(units covered by rent freeze) & $(0.012)$ & $(0.017)$ & $(0.024)$ \\
Post-A & & -0.009 & \\
Transition & & $(0.013)$ & \\
& -0.007 & & \\
Post-E & $(0.010)$ & & -0.018 \\
Treatment $\times$ Post-A & -0.018 & & $(0.020)$ \\
Treatment $\times$ Transition & $(0.017)$ & & \\
Treatment $\times$ Post-E & & 0.007 & \\
& -0.008 & & $-0.075^{* * *}$ \\
\hline Housing characteristics & $(0.011)$ & & $\checkmark$ \\
\hline Number of observations & $-0.113^{* * *}$ & & 3,314 \\
Adjusted R ${ }^{2}$ & $(0.019)$ & & 0.830 \\
\hline \hline
\end{tabular}

Notes: Standard errors shown in parentheses. The GAMs estimated include the variables location (smooth term), age (smooth term), first time occupation, living area, number of rooms, garden, balcony/terrace, fitted kitchen, parking, elevator, separate toilet. The full set of results are reported in Table 11. Significance is indicated using standard notation: $\cdot \mathrm{p}$-value $<0.1 ;{ }^{*} \mathrm{p}$-value $<0.05$; ${ }^{* *}$ p-value $<0.01 ;{ }^{* * *}$ p-value $<0.001$

We interpret changes in the volume of ads posted as a measure of turbulence on the supply side. Therefore, we assess the number of newly posted ads per week. Table 5 and Figure 7 report the results: While there are hardly any noticeable differences between the PRE and TRANS period, the ultimate enactment of the policy led to remarkable disruptions. The number of weekly advertised available housing units to rent halved from more than 600 per week before announcement to less than 300 only once the policy was implemented. ${ }^{19}$ The changes are statistically significant as indicated by the non-overlapping whiskers (95\% coverage intervals) in Figure 7 and as formally confirmed by Tukey Post-Hoc tests (Tukey, 1949). Full results are reported in Table 15 in the appendix.

\footnotetext{
${ }^{19}$ Incomplete weeks are excluded from the analysis.
} 


\begin{tabular}{|c|c|c|c|c|}
\hline & & \multicolumn{3}{|c|}{ Number of new ads per week } \\
\hline & & Mean & Median & Interquartile Range \\
\hline \multicolumn{5}{|c|}{ Rent Advertisements } \\
\hline \multirow[t]{3}{*}{ PRE } & 1 Jan 2018 - 3 June 2019 & 628.55 & 639.50 & 152.75 \\
\hline & ...thereof in treatment group & 510.04 & 517.00 & 98.25 \\
\hline & ...thereof in control group & 118.51 & 115.50 & 29.50 \\
\hline \multirow[t]{3}{*}{ TRANS } & 4 June 2019 - 22 Feb 2020 & 614.97 & 619.00 & 105.00 \\
\hline & ...thereof in treatment group & 509.14 & 522.00 & 79.00 \\
\hline & ...thereof in control group & 105.84 & 106.00 & 36.00 \\
\hline \multirow[t]{3}{*}{ POST } & 23 Feb 2020 - 30 June 2020 & 276.28 & 262.50 & 79.75 \\
\hline & ...thereof in treatment group & 224.00 & 223.50 & 50.50 \\
\hline & ...thereof in control group & 52.28 & 54.00 & 19.50 \\
\hline POST-2018 & 23 Feb 2018 - 30 June 2018 & 598.18 & 587.00 & 89.00 \\
\hline POST-2019 & 23 Feb 2019 - 30 June 2019 & 651.41 & 644.00 & 92.00 \\
\hline \multicolumn{5}{|c|}{ Sales Advertisements } \\
\hline PRE & 1 Jan 2018 - 3 June 2019 & 143.85 & 140.50 & 41.00 \\
\hline TRANS & 4 June 2019 - 22 Feb 2020 & 126.41 & 126.00 & 31.00 \\
\hline POST & 23 Feb 2020 - 30 June 2020 & 105.83 & 107.50 & 19.25 \\
\hline POST-2018 & 23 Feb 2018 - 30 June 2018 & 144.53 & 141.00 & 23.00 \\
\hline POST-2019 & 23 Feb 2019 - 30 June 2019 & 140.24 & 133.00 & 19.00 \\
\hline
\end{tabular}

Notes: The number of new ads for apartments to rent or sale per week measures the volume changes on the supply side. Numbers are reported for all types of flats as well as for rental advertisements separately for those falling into the treatment and control group, respectively. For comparability across seasons, the trade volume for usual activity between 23 February and 30 June are included for the two preceding years 2018 and 2019. For the calculations, all ads fulfilling our selection procedure described in section 4 are considered. The data are visualized in Figure 7.

Repeating the same exercise for sales advertisements, we also observe a lower number of advertisements in the POST period, yet changes are less pronounced and not significant.

The volume can also vary across seasons. Hence, we additionally compare the volume in the 2020 POST-treatment period to the exactly same time span in 2018 and 2019. The transaction volume in the two preceding years is indistinguishable from that in the 2020 PRE and TRANS periods. Hence, the volume effect we document here is a unique feature unambiguously linked to the rent freeze. 
Figure 7: Number of Newly Posted Rent and Sales Ads Per Week
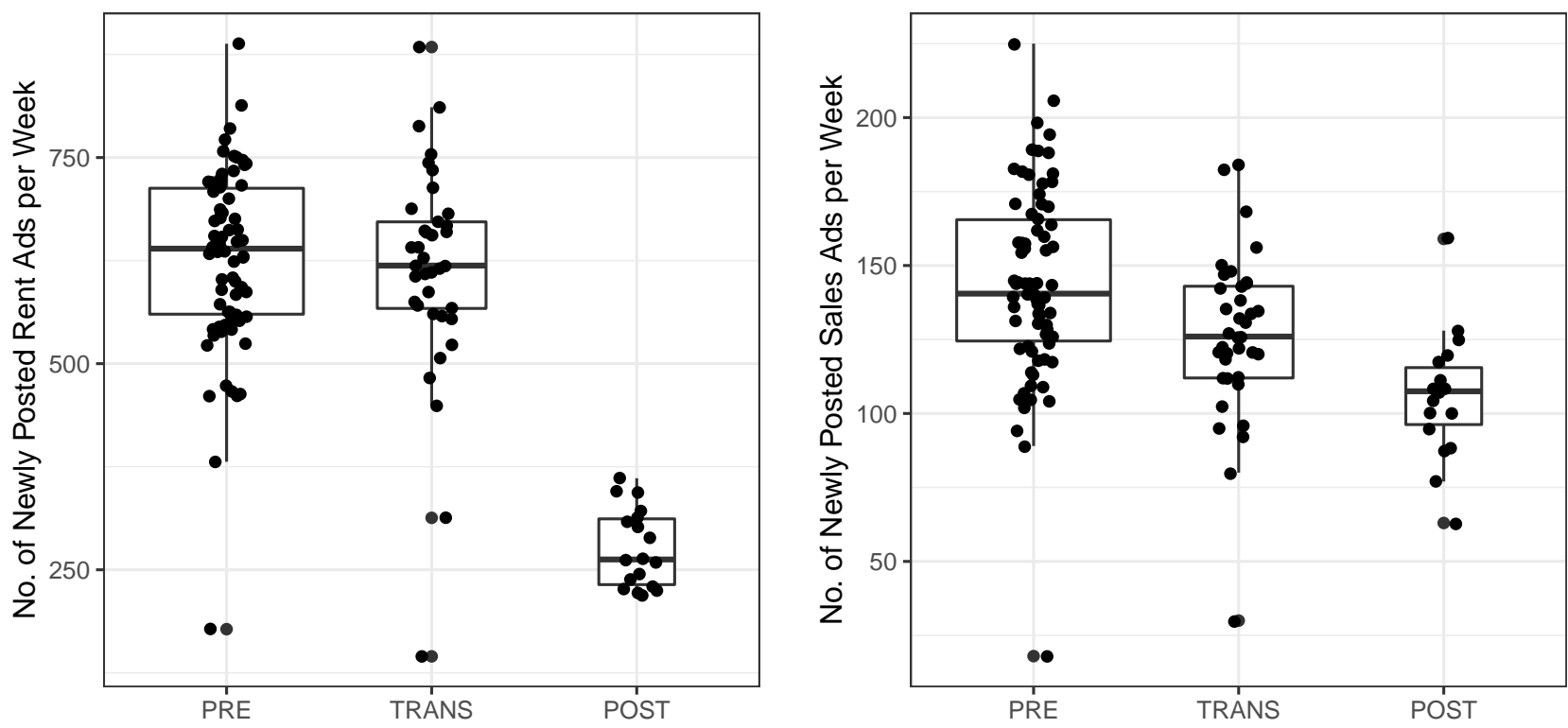

Notes: The boxplots depict the number of newly posted rent (left) and sales (right) advertisements per week separately for the PRE, TRANS and POST period as defined in Table 5. Each dot represents a unique full week. Corresponding numeric results are presented in Table 5.

It is important to note that the volume of both types of flats falls, and that, roughly by the same rate (see split ups in Table 5): those being directly captured by the rent freeze as well as those exempted. At first, we would have expected that during the transition period, particularly the transaction volume of exempted units would fall, while those being covered by the policy would have been advertised rather sooner than later. Overall, we do not find convincing evidence thereof. Thus, the decrease in transaction volume can primarily hint toward increased insecurity and ambiguity displacing economic activity.

In this context, it is important to note that the long-term effects are ambiguous, mainly as rents for flats in newly constructed or substantially refurbished buildings are exempt from the rent freeze. Our findings conform with two lines of thought: Taking existing apartments entirely off the rental market (i.e., not re-advertising rental units upon vacancy but rather selling or using them for different purposes) or substantially refurbishing it before re-advertisement. If the latter becomes the norm, Berlin's housing stock will eventually be radically transformed. Besides, if this channel indeed turns out to be a major one, Berlin's housing market may expect 
a wave of new or substantially renovated units offered for rent in the near future. Hence, it will be important to monitor the evolution in rents separately for new or substantially refurbished apartments, and older properties. Put differently, monitoring a single overall rent price index will hide insightful variation.

\subsection{Microsimulation}

\subsubsection{Overall Compliance}

We impute valid rents under the rent freeze regime using the information provided in the ads and additionally append them with external data from the Mietspiegel 2019 (see footnote 14). Thereby, we implement the rules originally stemming from the rent brake as well as the additional ones related to the rent freeze.

In particular, the Mietspiegel provides detailed information about the quality of location resulting in a classification of addresses into simple, average, and good locations. In addition, the maximum rent per square meter depends mainly on the construction year and the provision of basic equipment (heating and a bathroom) as reported in Table 6 .

We use these imputed valid rents and compare them to the advertised rent. For advertisements posted after the enactment, this provides a straight-forward measure of compliance. For the preceding transition and pre-announcement periods, we yield a measure whether and, if so, where the rent freeze leads to market disruptions.

It is important to mention the limitations of our imputation strategy as we may miss some exceptions, since the relevant information may simply not be mentioned in the advertisement. This includes most importantly imprecise address information, which impedes exact matching with the Mietspiegel. Moreover, for older dwellings the existence of heating and a bathroom determines the general allowed rent level. This information is neither unambiguously nor always explicitly contained in advertisements. We indirectly measure the existence of this equipment: if there is any kind of hint in the ad about the heating system and bathroom - i.e., "central heating" or additional "guest WC" - simply mentioned in the ad, assuming its existence is straight-forward. Yet, this is not always the case and we may mis-allocate quite some properties when relying on that only. Additionally, we make use of the overall classification provided by Empirica Systeme. In case of an overall rating of either good or excellent, we assume the existence of these basic facilities. Even more ambiguous is the add-on due to "modern 
equipment". Again, we follow the conservative approach and require an overall classification of good or excellent. Rents can be raised by up to $15 \%$, if the flat is situated in a two-family house. However, in our sample we only consider rental dwellings in multi-family houses.

Table 6: Percentage Deviation between the Advertised Rent and Valid Rent

\begin{tabular}{|c|c|c|c|}
\hline & PRE & TRANS & POST \\
\hline & \multicolumn{3}{|c|}{ Exempt from Rent Freeze } \\
\hline \multicolumn{4}{|l|}{ Deviation } \\
\hline Mean & 4.17 & 4.62 & 4.16 \\
\hline Median & 4.41 & 4.40 & 3.56 \\
\hline$Q_{10}$ & 0.18 & 0.45 & 0.36 \\
\hline$Q_{25}$ & 2.29 & 2.31 & 1.19 \\
\hline$Q_{75}$ & 6.17 & 6.43 & 6.24 \\
\hline$Q_{90}$ & 9.95 & 10.5 & 11.40 \\
\hline \multirow[t]{2}{*}{ Interquartile Range } & 3.88 & 4.12 & 5.05 \\
\hline & \multicolumn{3}{|c|}{ Covered by Rent Freeze } \\
\hline \multicolumn{4}{|l|}{ Deviation } \\
\hline Mean & 1.78 & 0.88 & 0.77 \\
\hline Median & 1.09 & 1.56 & -0.11 \\
\hline$Q_{10}$ & -1.40 & -1.38 & -1.96 \\
\hline$Q_{25}$ & -0.35 & -0.41 & -1.15 \\
\hline$Q_{75}$ & 3.24 & 2.92 & 1.92 \\
\hline$Q_{90}$ & 7.63 & 7.16 & 6.62 \\
\hline Interquartile Range & 3.58 & 3.07 & 3.25 \\
\hline Number of Observations & 31,672 & 30,738 & 6,478 \\
\hline
\end{tabular}

Notes: Deviations are computed as the difference between the valid rent and the advertised rent per square meter including permitted overshooting by $20 \%$. Periods are defined as in Table 5 . Only observations with a start and end date in the same period are allocated to the respective periods.

Acknowledging these shortcomings, we compute deviations (in EUR) conservatively via

$$
\text { Deviation }=\text { Advertised Rent per } \mathrm{m}^{2}-\left(1.2 \cdot \text { Valid Rent per } \mathrm{m}^{2}\right) \text {. }
$$

In other words, we include a potential error margin of $20 \%$ as such kind of over-shooting is explicitly allowed. Overall, we hence are likely to identify the upper bound of the number of dwellings exceeding the maximum allowed rent. Also, the amount of mismatches in EUR is, per construction, an upper bound. We compute deviations separately for the three different periods 


\section{Figure 8: Density Plots for Deviations from Valid Rent}
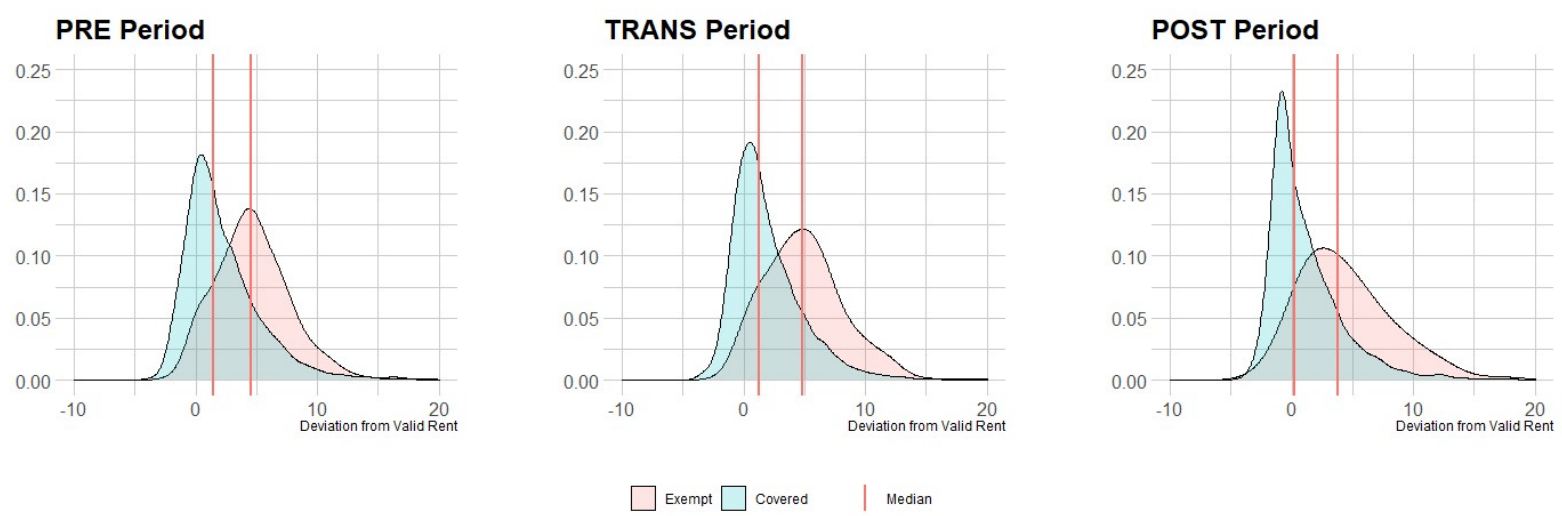

Notes: Deviations are computed as the difference between the valid rent and the advertised rent per square meter including permitted overshooting by $20 \%$. Periods are defined as in Table 5 . Only observations with a start and end date in the same period are allocated to the respective periods.

in order to detect systematic deviations. Also, we do so separately for properties covered by the rent freeze and those exempt.

Table 6 and Figure 8 report the results. As expected, units exempt from the rent freeze generally do not comply to the price restrictions binding for those covered. Most importantly, the regulated dwellings advertised in the POST period by large means do not follow the restrictions imposed by the by-then legally binding rent freeze. Only roughly $50 \%$ are indeed negative indicating a lower advertised rent than the valid rent. Put differently, only about half of all advertisements do indeed follow the rules. Yet, the absolute difference in mean/median deviations between covered and exempt units is larger in the TRANS and POST periods than in the PRE period indicating an increase in the degree of homogeneity in asking rents. Importantly, the lower the rent quintile, the more negative are the deviations between the advertised and the valid rent, especially after the enactment of the rent freeze. This means that the freeze is more effective in the affordable rent segment.

Importantly, asking rents are per definition not restricted - only realized rents indeed are. Yet, such information likely induces confusion and potentially animates to tricking tenants unaware of how to exactly compute a valid rent. Particularly the last point raises concerns whether complex laws affecting the vast majority (Germany-wide homeowner rate is $46.5 \%$, 
while that in Berlin is only $17.4 \%)^{20}$ should in fact be designed in such complex terms. The provision of easy-to-handle automatic valuation and evaluation tools may be necessary.

\subsubsection{Regional Variation}

We assess regional variation in coverage and compliance rates. Therefore, we compute key measures separately for each of the Berlin's 12 districts (see Table 7). Again, we focus on advertisements activated after the rent freeze's enactment.

On average, $83 \%$ of all advertisements posted are covered by this policy. The district-specific shares, however, reveal substantial variation: between $67 \%$ in Friedrichshain-Kreuzberg and $95 \%$ in Spandau.

\section{Table 7: Variation after Enactment across Districts}

\begin{tabular}{lcc}
\hline \hline & $\begin{array}{c}\text { Coverage Rate } \\
\text { Charlottenburg-Wilmersdorf }\end{array}$ & $\begin{array}{c}\text { Median Rent Deviation } \\
\text { of Covered Ads } \\
{[\text { [EUR] }}\end{array}$ \\
\cline { 2 - 3 } Friedrichshain-Kreuzberg & 83.59 & -0.111 \\
Lichtenberg & 66.85 & 2.608 \\
Marzahn-Hellersdorf & 73.58 & -1.071 \\
Mitte & 82.80 & -0.868 \\
Neukölln & 71.36 & 1.286 \\
Pankow & 90.07 & 0.161 \\
Reinickendorf & 82.90 & 0.282 \\
Spandau & 92.29 & 0.002 \\
Steglitz-Zehlendorf & 94.85 & -0.778 \\
Tempelhof-Schöneberg & 92.04 & 0.636 \\
Treptow-Köpenick & 87.68 & 0.138 \\
Overall Mean & 74.79 & -0.410 \\
Overall Median & 82.73 & 0.156 \\
\hline \hline
\end{tabular}

Notes: The table reports key figures by district: Rent Freeze Coverage Rates (number of ads covered by rent freeze over all posted ads), Median Deviation of Advertised Rents (per square meter) from Valid Rents. Overall means and medians are calculated across district-specific values. Numbers refer to advertisements posted and closed between 23 February and 30 June 2020.

Sources: Authors' calculations based on rent advertisements collected by Empirica Systeme.

\footnotetext{
${ }^{20}$ See the homeownership rate statistics (Eigentümerquote nach Bundesländern im Zeitvergleich) of the Federal Statistical Office of Germany; https://www.destatis.de/DE/Themen/Gesellschaft-Umwelt/Wohnen/ Tabellen/eigentuemerquote-nach-bundeslaender.html.
} 
We further compute average deviations of posted rents from the valid rent. Table 6 reports the overall figures for covered units and finds large deviations after the rent freeze's enactment. Looking at Berlin as a whole, roughly $50 \%$ of all ads followed the restrictions. Again, the regional variation is substantial: While more than $50 \%$ of advertised rents follow requirements in Charlottenburg-Wilmersdorf, Lichtenberg, Marzahn-Hellersdorf, Spandau and Treptow-Köpenick, the large deviations are, in fact, driven by advertisements referring to units located in the affluent central districts Friedrichshain-Kreuzberg and Mitte, as well as the traditionally affluent district Steglitz-Zehlendorf in the South-West of Berlin (see Table 16 in Appendix for district-specific demographic information). In part, these regional differences can be explained by an inaccurate representation of location in the Mietspiegel that does not capture the actual spatial effects, as noted by Kauermann and Windmann (2016); Rendtel and Frink (2020). Indeed, the average location in the city center is not worth the same as the average location at the periphery. Thus, the Mietspiegel tends to undervalue the dwellings located in the center and overvalue those located at the periphery.

\section{Robustness Checks}

\subsection{Alternative Control Group}

An alternative specification of the control group includes all apartments that were built or offered for first-time occupancy (either in newly built or substantially refurbished flats) after 1 January 2014. This classification is less strict since it might also cover relatively old flats that are nonetheless offered for first-time occupancy. We re-estimate the main results for this alternative, less strict specification of the control group. This alternative specification still yields the same significant coefficients as before (see Table 8). The values even stay the same for the pre and post announcement (Pre-Pre and Pre-Post) DiD regression and change only slightly in the Post-Pre and Post-Post DiD models.

\subsection{Choice of periods}

A possible side effect of any restrictive rent policy may affect the type of dwellings offered for rent. Plausible reasons of such a change include, for instance, differences in the type of landlords. Some of them can be able to keep a flat empty while awaiting a final decision of the 


\section{Table 8: Alternative Control Group}

\begin{tabular}{|c|c|c|c|}
\hline \multirow[b]{3}{*}{$\begin{array}{l}\text { Treatment } \\
\text { (units covered by rent freeze) } \\
\text { Post-A }\end{array}$} & \multicolumn{3}{|c|}{ Response: Monthly Rent (log) } \\
\hline & \multirow{2}{*}{$\begin{array}{c}\text { Strategy A } \\
-0.078^{* * *} \\
(0.013)\end{array}$} & \multicolumn{2}{|c|}{ Strategy B } \\
\hline & & $\begin{array}{c}-0.075^{* * *} \\
(0.020) \\
-0.009 \\
(0.012)\end{array}$ & $\begin{array}{c}-0.109^{* * *} \\
(0.026)\end{array}$ \\
\hline Transition & $\begin{array}{l}-0.008 \\
(0.009)\end{array}$ & & \\
\hline Post-E & $\begin{array}{l}-0.030 \\
(0.016)\end{array}$ & & $\begin{array}{l}-0.031 \\
(0.019)\end{array}$ \\
\hline Treatment $\times$ Post-A & & $\begin{array}{c}0.006 \\
(0.014)\end{array}$ & \\
\hline Treatment $\times$ Transition & $\begin{array}{l}-0.007 \\
(0.010)\end{array}$ & & \\
\hline Treatment $\times$ Post-E & $\begin{array}{c}-0.100^{* * *} \\
(0.018)\end{array}$ & & $\begin{array}{c}-0.059^{* *} \\
(0.022)\end{array}$ \\
\hline Housing characteristics & $\checkmark$ & $\checkmark$ & $\checkmark$ \\
\hline Number of observations & 26,842 & 5,311 & 3,314 \\
\hline Adjusted $\mathrm{R}^{2}$ & 0.832 & 0.843 & 0.830 \\
\hline
\end{tabular}

Notes: Standard errors shown in parentheses. The full set of results are reported in Table 11. Significance is indicated using standard notation: ' p-value $<0.1 ;{ }^{*}$ p-value $<0.05 ;{ }^{* *}$ p-value $<0.01 ;{ }^{* * *}$ p-value $<0.001$.

courts and establish a suitable rental agreement only thereafter. This would be much harder for owners depending more strongly on the regular income flows from rental agreements. Other potential reason is the possibility of taking the apartment off the rental market for good. It could be used by owners or their relatives themselves, sold, or simply kept vacant whenever an owner believes that depreciation and associated maintenance costs due to living in an apartment exceed the reduced potential rent income.

The transmitting channels potentially at work here are numerous. Although we observe neither socio-economic nor demographic characteristics of the owners, we tackle this issue in an indirect way by assessing the changes in the types of housing units for rent over the three periods under investigation. Therefore, Table 12, Table 13 and Table 14 in Appendix report summary statistics separately compiled for the pre-announcement, transition, and post-enactment periods. 
Except for the previously discussed number of observations, we do not find any systematic differences in characteristics across periods and hence conclude that no systematic change in the type of properties on the market occurred.

\subsection{Price Effects and Hedonic Controls}

We re-estimate the DiD models estimated in subsection 5.3 leaving out the large set of hedonic controls. We argued in favor of including them as they capture fundamental rentdetermining features. Hence, we refrain from over-interpreting the effect sizes, yet non-significance of our key treatment variables would create serious doubts.

Table 9: Neglecting Hedonic Controls

\begin{tabular}{|c|c|c|c|}
\hline \multirow[b]{3}{*}{$\begin{array}{l}\text { Treatment } \\
\text { (units covered by rent freeze) } \\
\text { Post-A }\end{array}$} & \multicolumn{3}{|c|}{ Response: Monthly Rent (log) } \\
\hline & \multirow{2}{*}{$\begin{array}{c}\text { Strategy A } \\
-0.456^{* * *} \\
(0.023)\end{array}$} & \multicolumn{2}{|c|}{ Strategy B } \\
\hline & & $\begin{array}{c}-0.456^{* * *} \\
(0.023) \\
-0.014 \\
(0.029)\end{array}$ & $\begin{array}{c}-0.574^{* * *} \\
(0.027)\end{array}$ \\
\hline Transition & $\begin{array}{c}0.013 \\
(0.022)\end{array}$ & & \\
\hline Post-E & $\begin{array}{c}0.088^{*} \\
(0.037)\end{array}$ & & $\begin{array}{c}0.049 \\
(0.040)\end{array}$ \\
\hline Treatment $\times$ Post-A & & $\begin{array}{c}0.013 \\
(0.032)\end{array}$ & \\
\hline Treatment $\times$ Transition & $\begin{array}{c}-0.040 \\
(0.025)\end{array}$ & & \\
\hline Treatment $\times$ Post-E & $\begin{array}{c}-0.264^{* * *} \\
(0.042)\end{array}$ & & $\begin{array}{c}-0.146^{* *} \\
(0.045)\end{array}$ \\
\hline Housing characteristics & $x$ & $x$ & $x$ \\
\hline Number of observations & 26,842 & 5,311 & 3,314 \\
\hline Adjusted $\mathrm{R}^{2}$ & 0.142 & 0.127 & 0.207 \\
\hline
\end{tabular}

Notes: The table extends results reported in Table 4. Standard errors shown in parentheses. Significance is indicated using standard notation: · p-value $<0.1 ;{ }^{*}$-value $<0.05 ;{ }^{* *}$ p-value $<0.01 ;{ }^{* * *}$-value $<0.001$.

Reassuringly, however, both the direction and significance of results remain unchanged as reported in Table 9. Nonetheless, as compared to the core results, the effect sizes are much larger. Hence, hedonic control variables are indeed important to be included to ensure a clean 
measurement thereof. The well established battery of relevant housing characteristics used for hedonic price modelling helps also here to precisely filter policy effects and disentangle them from variation stemming from changes in the (per construction always varying) mix of dwelling characteristics as already claimed by Rosen (1974).

In fact, describing changes in advertised rent prices solely by dummies differentiating treated and untreated dwellings explains already a large chunk of variability. The model aimed for measuring the rent freeze's announcement effects achieves an adjusted $R^{2}$ value of $12.7 \%$, which is solely driven by the explanatory power of general price differences between the control and treatment group. The same model design (equal in degrees of freedom) yet shifted in time to measure the enactment effect achieves an adjusted $R^{2}$ value of $20.7 \%$. The substantial increase in explanatory power constitutes a second convincing argument supporting the policy's effectiveness.

\subsection{Geo-coding}

A source of insecurity stems from the fact that geographic co-ordinates (longitudes and latitudes) are estimated in case of absence of a precise address mentioned in the ad. We use the randomly assigned quasi-location instead of exact locations provided by Empirica Systeme. Depending on the details provided in the ad (e.g., district only or street name without street number) the radius of the circle overlapping the quasi-location increases. For instance, in the case of a missing street number, the circle associated with the provided quasi-location overlaps the true location with a $95 \%$ probability. Hence, the larger the circle's radius the less the provided location should be trusted.

The main models, only include properties with known exact geo-location. And the vast majority, in fact, does include this information. Nonetheless, we re-estimate the main model results on the full data set including also quasi-locations. Thus, we weigh all observations by the inverse of this quasi-location's radius resulting in an information-weighted estimation of the main model; see Table 10, columns (1) and (2). Additionally, we include all observations without information-weighting; see columns (3) and (4). Neither significance levels nor the estimated parameters deviate considerably from the originally estimated model. Moreover, overall goodness-of-fit measures remain practically unchanged. Our conservative approach to exclude observations without exact geo-location is hence considered to be very reliable. 
Table 10: Estimation Results: Full Data Set

\begin{tabular}{|c|c|c|c|c|}
\hline & \multicolumn{4}{|c|}{ Response: Monthly Rent (log) } \\
\hline & (1) & (2) & (3) & (4) \\
\hline $\begin{array}{l}\text { Treatment } \\
\text { (apartments covered by rent freeze) }\end{array}$ & $\begin{array}{c}-0.076^{* * *} \\
(0.015)\end{array}$ & $\begin{array}{c}-0.071^{* *} \\
(0.022)\end{array}$ & $\begin{array}{c}-0.076^{* * *} \\
(0.015)\end{array}$ & $\begin{array}{c}-0.076^{* * *} \\
(0.021)\end{array}$ \\
\hline Post period & $\begin{array}{l}-0.011 \\
(0.012)\end{array}$ & $\begin{array}{l}-0.021 \\
(0.018)\end{array}$ & $\begin{array}{l}-0.009 \\
(0.011)\end{array}$ & $\begin{array}{l}-0.012 \\
(0.016)\end{array}$ \\
\hline Treatment $\times$ Post period & $\begin{array}{l}0.008 \\
(0.013)\end{array}$ & $\begin{array}{c}-0.073^{* * *} \\
(0.020)\end{array}$ & $\begin{array}{c}0.009 \\
(0.013)\end{array}$ & $\begin{array}{c}-0.075^{* * *} \\
(0.018)\end{array}$ \\
\hline Housing characteristics & $\checkmark$ & $\checkmark$ & $\checkmark$ & $\checkmark$ \\
\hline Post period $=$ Policy Announcement & $\checkmark$ & $x$ & $\checkmark$ & $x$ \\
\hline Post period=Policy Enactment & $x$ & $\checkmark$ & $x$ & $\checkmark$ \\
\hline Information weighting & $\checkmark$ & $\checkmark$ & $x$ & $x$ \\
\hline No. of Observations & 6,350 & 4,061 & 6,350 & 4,061 \\
\hline Adjusted $R^{2}$ & 0.843 & 0.832 & 0.849 & 0.841 \\
\hline
\end{tabular}

Notes: The full data set used includes observations with and without exact address. Standard errors are shown in parentheses. The full set of results are reported in Table 11. Significance is indicated using standard notation: $\cdot \mathrm{p}$-value $<0.1{ }^{*}{ }^{*} \mathrm{p}-\mathrm{value}<0.05$; ${ }^{* *}$ p-value $<0.01 ;{ }^{* * *}$-value $<0.001$.

\section{Conclusions}

In this study, we assess the short-term effects of the rent freeze - a newly introduced rigorous rent control tool in Berlin. For this purpose, we estimate difference-in-differences models supplemented by a large battery of established hedonic characteristics accounting for justified heterogeneity in rent prices. This approach guarantees a precise measurement of the effect size.

As intended by policy-makers, the supply side reacted to the enactment of the rent freeze enactment in February 2020: advertised rent prices indeed dropped substantially. As compared to non-regulated properties, these price drops are highly significant - both in economic and statistical terms. These results survive an ample set of robustness checks. At the same time, asking rents surge in Berlin's satellite city Potsdam and further neighboring municipalities indicating a substitution effect.

Next to the price effects, we identify a considerable decline in the number of advertised rental 
units. This sizable - yet potentially non-intended - side effect hampers renter's flexibility and adaptability. In particular, newcomers and young first-time renters will face hurdles finding a suitable place to live. The drop in supply can be transitory, yet could also display the prelude to even harsher housing searching conditions in the future. Potentially, existing flats can be replaced by the newly built ones or, if financially and technically feasible, substantially refurbished. Both would overall lead to higher rents as more affordable, existing units will be replaced by newer and more expensive ones.

In a micro-simulation exercise, we impute valid rents according to the rules of the rent freeze. We do not find large-scale compliance with these rules among newly posted ads after the legally binding enactment of the rent freeze. Yet, we find a large variation in consequences across Berlin's districts. Although location affects the valid rent according to the rent freeze's design, observed heterogeneity seems to be even larger: not all locations are indeed equal. The gap between covered and exempt units hence increases in many dimensions leading to more and more distinct sub-markets.

The overall conclusions are mixed. In particular, rigorous price restrictions seem to be short-sighted, if they come without supplemental strategies to increase the supply of rental units. Whether the exemption of new construction from rigorous rent caps will act as strong enough stimulus to fill up the supply holes left by the rent freeze and the insecurities it invoked is to be seen. An overall welfare increasing effect is doubtful. 


\section{References}

de Haan, J. and W. E. Diewert (Eds.) (2013). Handbook on Residential Property Prices Indices (RPPIs). Methodologies and Working Papers. Luxembourg: Eurostat.

Diamond, R., T. McQuade, and F. Qian (2019). The effects of rent control expansion on tenants, landlords, and inequality: Evidence from San Francisco. American Economic Review 109 (9), 3365-94.

Francke, M. and M. Korevaar (2020). Housing markets in a pandemic: Evidence from historical outbreaks. SSRN 3566909.

Glaeser, E. L. and E. F. Luttmer (2003). The misallocation of housing under rent control. American Economic Review 93(4), 1027-1046.

Housing Europe (2017). The state of housing in the EU 2017. European Federation of Public, Cooperative and Social Housing.

Investitionsbank Berlin (2020). IBB Housing Market Report 2019: Summary.

Kauermann, G. and M. Windmann (2016). Mietspiegel heute. AStA Wirtschafts-und Sozialstatistisches Archiv 10(4), 205-223.

Kholodilin, K. (2017a). Quantifying a century of state intervention in rental housing in Germany. Urban Research and Practice 10(3), 267-328.

Kholodilin, K. A. (2017b). Wanderungssalden der deutschen Metropolen. Der Landkreis 1-2, 45-48.

Kholodilin, K. A. (2020). Long-term, multicountry perspective on rental market regulations. Housing Policy Debate $30(6), 994-1015$.

Kholodilin, K. A., L. Limonov, and S. R. Waltl (2019). Housing rent dynamics and rent regulation in St. Petersburg (1880-1917). Luxembourg Institute of Socio-Economic Research (LISER) Working Paper Series 3.

Leamer, E. E. (2007). Housing is the business cycle. National Bureau of Economic Research. 
Mense, A., C. Michelsen, and K. A. Kholodilin (2019). Rent control, market segmentation, and misallocation: Causal evidence from a large-scale policy intervention. DIW Discussion Papers No. 1832.

Rendtel, U. and N. Frink (2020). Wie zuverlässig ist der Berliner Mietspiegel? Eine Validierung anhand des Mikrozensus Wohnungsmoduls. Mimeo available at https://www.wiwiss.fu-berlin.de/fachbereich/vwl/ls_rendtel/Forschung/ Validierung_Mietspiegel.pdf.

Rosen, S. (1974). Hedonic prices and implicit markets: Product differentiation in pure competition. Journal of Political Economy 82(1), 34.

Thomschke, L. (2019). Regional impact of the German rent brake. German Economic Review 20(4), 892-912.

Tukey, J. W. (1949). Comparing individual means in the analysis of variance. Biometrics 5(2), 99-114.

Waltl, S. R. (2016). A hedonic house price index in continuous time. International Journal of Housing Markets and Analysis 9(4), 648-670.

Waltl, S. R. (2018). Estimating quantile-specific rental yields for residential housing in Sydney. Regional Science and Urban Economics 68, 204-225.

Wood, S. N., N. Pya, and B. Säfken (2016). Smoothing parameter and model selection for general smooth models. Journal of the American Statistical Association 111(516), 15481563. 


\section{Appendix: Supplemental Figures and Tables}

Figure 9: Common Trend Assumption

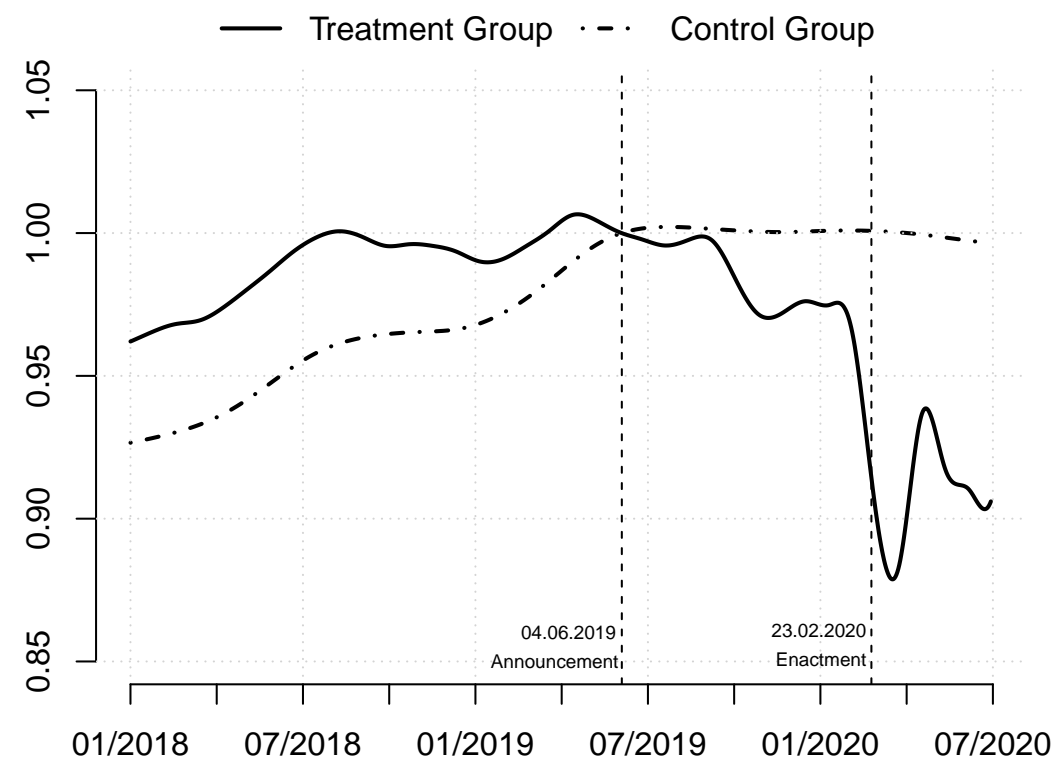

Notes: The indices show the general trend of prices in the treatment vs. control group between 2018 and the end of the second quarter 2020. Indices are normalized to 4 June 2019, when the announcement took place. The time-continuous indices follow the methodology developed in Waltl (2016) based on adaptive smoothing techniques. 


\section{Figure 10: Nominal Sales Indices: Hypothetical Treatment vs. Control Group}

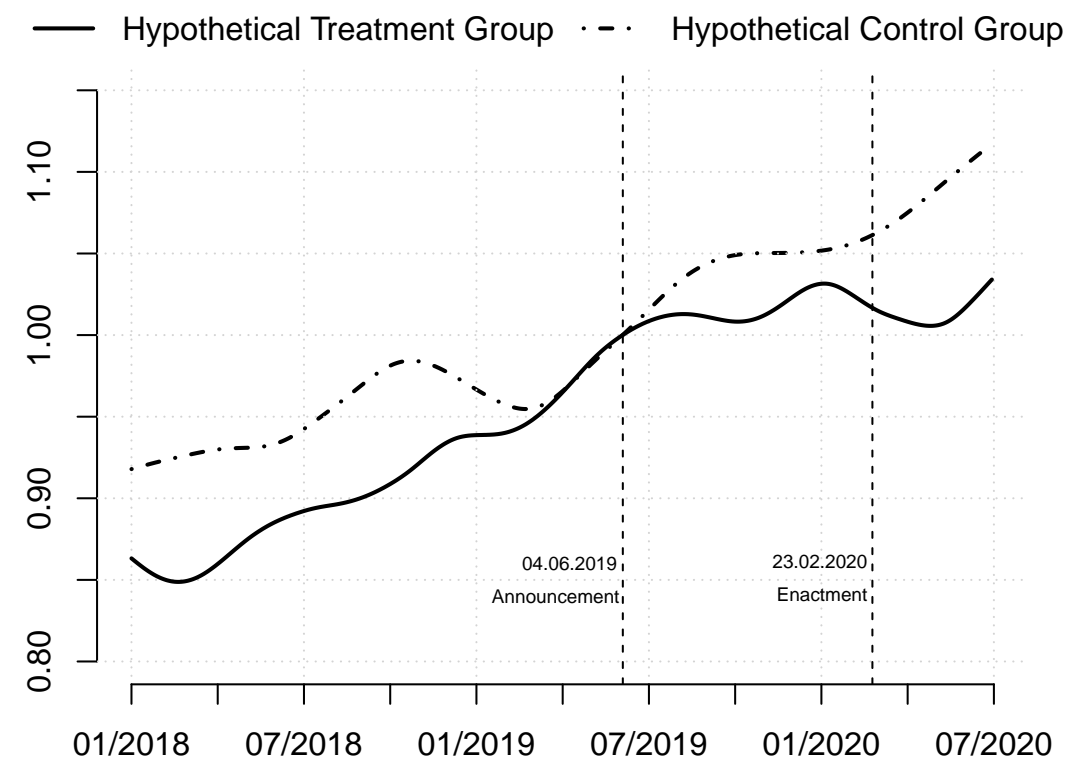

Notes: The indices unveil the general trends between the hypothetical treatment and control groups in the sales market between 2018 and the end of the second quarter 2020. Hypothetical means apartments that would be covered by the rent freeze if they were rented out. Indices are normalized to the day of the announcement of the rent freeze (4 June 2019). The time-continuous indices follow the methodology developed in Waltl (2016) based on adaptive smoothing techniques. 
Table 11: DiDs - Full Results

\begin{tabular}{|c|c|c|c|c|c|c|}
\hline \multirow[b]{2}{*}{ Intercept } & \multicolumn{2}{|c|}{$\begin{array}{c}\text { Pre-/Post } \\
\text { Announcement }\end{array}$} & \multicolumn{2}{|c|}{$\begin{array}{l}\text { Pre-/Post } \\
\text { Enactment }\end{array}$} & \multicolumn{2}{|c|}{ Pre-Trans-Post } \\
\hline & $\begin{array}{c}5.608 \\
(0.019)\end{array}$ & $* * *$ & $\begin{array}{c}5.503 \\
(0.027)\end{array}$ & $* * *$ & $\begin{array}{c}5.587 \\
(0.012)\end{array}$ & $* * *$ \\
\hline First Time Occupation & $\begin{array}{c}0.128 \\
(0.012)\end{array}$ & $* * *$ & $\begin{array}{c}0.137 \\
(0.018)\end{array}$ & $* * *$ & $\begin{array}{c}0.122 \\
(0.006)\end{array}$ & $* * *$ \\
\hline Living Area & $\begin{array}{c}0.009 \\
(0.000)\end{array}$ & $* * *$ & $\begin{array}{c}0.011 \\
(0.000)\end{array}$ & $* * *$ & $\begin{array}{c}0.010 \\
(0.000)\end{array}$ & $* * *$ \\
\hline 2 Rooms & $\begin{array}{c}0.136 \\
(0.009)\end{array}$ & $* * *$ & $\begin{array}{c}0.133 \\
(0.013)\end{array}$ & $* * *$ & $\begin{array}{c}0.123 \\
(0.004)\end{array}$ & $* * *$ \\
\hline 3 Rooms & $\begin{array}{c}0.199 \\
(0.012)\end{array}$ & $* * *$ & $\begin{array}{c}0.185 \\
(0.017)\end{array}$ & $* * *$ & $\begin{array}{c}0.179 \\
(0.005)\end{array}$ & $* * *$ \\
\hline 4 Rooms & $\begin{array}{c}0.199 \\
(0.018)\end{array}$ & $* * *$ & $\begin{array}{c}0.167 \\
(0.026)\end{array}$ & $* * *$ & $\begin{array}{c}0.186 \\
(0.008)\end{array}$ & $* * *$ \\
\hline $5+$ Rooms & $\begin{array}{c}0.099 \\
(0.030)\end{array}$ & $* * *$ & $\begin{array}{l}-0.012 \\
(0.047)\end{array}$ & & $\begin{array}{c}0.029 \\
(0.014)\end{array}$ & $*$ \\
\hline Garden & $\begin{array}{c}0.050 \\
(0.009)\end{array}$ & $* * *$ & $\begin{array}{c}0.042 \\
(0.014)\end{array}$ & $* *$ & $\begin{array}{c}0.034 \\
(0.004)\end{array}$ & $* * *$ \\
\hline Balcony/Terrace & $\begin{array}{l}0.0450 \\
(0.009)\end{array}$ & $* * *$ & $\begin{array}{c}0.019 \\
(0.010)\end{array}$ & & $\begin{array}{c}0.037 \\
(0.003)\end{array}$ & $* * *$ \\
\hline Fitted Kitchen & $\begin{array}{c}0.169 \\
(0.007)\end{array}$ & $* * *$ & $\begin{array}{c}0.194 \\
(0.010)\end{array}$ & $* * *$ & $\begin{array}{c}0.165 \\
(0.003)\end{array}$ & $* * *$ \\
\hline Parking & $\begin{array}{c}0.054 \\
(0.009)\end{array}$ & $* * *$ & $\begin{array}{c}0.038 \\
(0.013)\end{array}$ & $* *$ & $\begin{array}{c}0.037 \\
(0.004)\end{array}$ & $* * *$ \\
\hline Elevator & $\begin{array}{c}0.028 \\
(0.008)\end{array}$ & $* * *$ & $\begin{array}{c}0.037 \\
(0.011)\end{array}$ & $* * *$ & $\begin{array}{c}0.036 \\
(0.003)\end{array}$ & $* * *$ \\
\hline Separate Toilet & $\begin{array}{c}0.026 \\
(0.012)\end{array}$ & $*$ & $\begin{array}{c}0.049 \\
(0.017)\end{array}$ & $* *$ & $\begin{array}{c}0.034 \\
(0.005)\end{array}$ & $* * *$ \\
\hline $\begin{array}{l}\text { s(longitude,latitude) } \\
\mathrm{s}(\text { age })\end{array}$ & $\begin{array}{c}214.27 \\
8.05\end{array}$ & $\begin{array}{ll}* * * & \text { (edf) } \\
* * * & \text { (edf) }\end{array}$ & $\begin{array}{c}186.023 \\
8.358\end{array}$ & $\begin{array}{ll}* * * & \text { (edf) } \\
* * * & \text { (edf) }\end{array}$ & $\begin{array}{c}292.08 \\
8.69\end{array}$ & $\begin{array}{ll}* * * & \text { (edf) } \\
* * * & \text { (edf) }\end{array}$ \\
\hline $\begin{array}{l}\text { Adj. } R^{2} \\
\text { GCV score } \\
\text { No. of Observations }\end{array}$ & $\begin{array}{c}0.84 \\
0.04 \\
5,311\end{array}$ & & $\begin{array}{c}0.83 \\
0.06 \\
3,314\end{array}$ & & $\begin{array}{c}0.83 \\
0.04 \\
26,842\end{array}$ & \\
\hline
\end{tabular}

Notes: The table reports the detailed results extending Table 4. Treatment effects are left out. The Generalized Cross Validation Score $(G C V)$ is used to determine smooth components (see Wood et al., 2016). For smooth terms, we report the effective degrees of freedom (edf). 


\section{Table 12: Summary Statistics - Pre-Announcement Period}

\begin{tabular}{|c|c|c|c|c|c|c|c|}
\hline & Mean & St. Dev. & Minimum & 1st Quartile & Median & 3rd Quartile & Maximum \\
\hline Monthly Rent [EUR] & 738.47 & 450.91 & 165.00 & 446.00 & 610.50 & 883.00 & $4,400.00$ \\
\hline Monthly Rent $\left[\mathrm{EUR} / \mathrm{m}^{2}\right]$ & 10.79 & 3.76 & 4.57 & 8.00 & 10.01 & 12.72 & 31.05 \\
\hline Age [years] & 61.23 & 39.35 & 1.00 & 31.00 & 53.00 & 100.00 & 156.00 \\
\hline Living Area $\left[\mathrm{m}^{2}\right]$ & 67.11 & 26.70 & 19.00 & 50.30 & 62.60 & 77.00 & 251.00 \\
\hline & & 1 room & 2 rooms & 3 rooms & 4 rooms & $5+$ rooms & \\
\hline Number of rooms [\%] & & 18.61 & 44.77 & 26.79 & 7.99 & 1.84 & \\
\hline Shares [\%] & & Yes & No & & & & \\
\hline First-Time Occupation & & 18.99 & 81.01 & & & & \\
\hline Garden & & 12.65 & 87.35 & & & & \\
\hline Balcony/Terrace & & 76.32 & 23.68 & & & & \\
\hline Fitted kitchen & & 41.09 & 58.91 & & & & \\
\hline Parking & & 19.62 & 80.38 & & & & \\
\hline Elevator & & 48.11 & 51.89 & & & & \\
\hline Separate Toilet & & 9.76 & 90.24 & & & & \\
\hline
\end{tabular}

No. of Observations

Notes: The table reports summary statistics of flats offered for rent in the period between 7 May 2019 and 03 June 2019 (28 8 days of PRE announcement period). The start of the placement of the advertisement is decisive for the division into periods. All advertisements also include geo-coded information of the location of the unit (longitudes and latitudes). 


\section{Table 13: Summary Statistics - Transition Period}

\begin{tabular}{|c|c|c|c|c|c|c|c|}
\hline & Mean & St. Dev. & Minimum & 1st Quartile & Median & 3rd Quartile & Maximum \\
\hline Monthly Rent [EUR] & 717.46 & 448.28 & 144.00 & 436.50 & 587.70 & 850.00 & $7,481.00$ \\
\hline Monthly Rent [EUR $\left./ \mathrm{m}^{2}\right]$ & 10.67 & 3.77 & 3.21 & 7.84 & 9.95 & 12.64 & 49.33 \\
\hline Age [years] & 62.47 & 39.64 & 0.00 & 32.00 & 55.00 & 102.00 & 220.00 \\
\hline Living Area $\left[\mathrm{m}^{2}\right]$ & 66.00 & 27.07 & 11.00 & 49.00 & 61.44 & 76.92 & 415.60 \\
\hline Number of Rooms [\%] & & $\begin{array}{c}1 \text { room } \\
20.56\end{array}$ & $\begin{array}{c}2 \text { rooms } \\
44.49\end{array}$ & $\begin{array}{c}3 \text { rooms } \\
25.86\end{array}$ & $\begin{array}{c}4 \text { rooms } \\
7.37\end{array}$ & $\begin{array}{c}5+\text { rooms } \\
1.72\end{array}$ & \\
\hline Shares [\%] & & Yes & No & & & & \\
\hline First-time occupation & & 16.45 & 83.55 & & & & \\
\hline Garden & & 11.36 & 88.64 & & & & \\
\hline Balcony/Terrace & & 72.21 & 27.79 & & & & \\
\hline Fitted kitchen & & 38.42 & 61.58 & & & & \\
\hline Parking & & 17.62 & 82.38 & & & & \\
\hline Elevator & & 48.03 & 51.97 & & & & \\
\hline Separate Toilet & & 9.83 & 90.17 & & & & \\
\hline No. of Observations & & & & & & & 23,057 \\
\hline
\end{tabular}




\section{Table 14: Summary Statistics - Post-Enactment Period}

\begin{tabular}{|c|c|c|c|c|c|c|c|}
\hline & Mean & St. Dev. & Minimum & 1st Quartile & Median & 3rd Quartile & Maximum \\
\hline Monthly Rent [EUR] & 701.26 & 533.95 & 153.00 & 363.40 & 536.80 & 877.20 & $4,982.00$ \\
\hline Monthly Rent $\left[\mathrm{EUR} / \mathrm{m}^{2}\right]$ & 10.03 & 4.53 & 4.41 & 6.44 & 8.90 & 12.06 & 46.67 \\
\hline Age [years] & 54.40 & 39.85 & 0.00 & 24.00 & 47.00 & 89.00 & 150.00 \\
\hline Living Area $\left[\mathrm{m}^{2}\right]$ & 67.17 & 29.22 & 15.00 & 48.97 & 62.00 & 77.83 & 280.00 \\
\hline & & 1 Room & 2 Rooms & 3 Rooms & 4 Rooms & $5+$ Rooms & \\
\hline Number of Rooms [\%] & & 21.88 & 43.75 & 24.20 & 8.04 & 2.14 & \\
\hline Shares [\%] & & Yes & No & & & & \\
\hline First-Time Occupation & & 13.93 & 86.07 & & & & \\
\hline Garden & & 12.32 & 87.68 & & & & \\
\hline Balcony/Terrace & & 74.64 & 25.36 & & & & \\
\hline Fitted kitchen & & 38.57 & 61.43 & & & & \\
\hline Parking & & 18.21 & 81.79 & & & & \\
\hline Elevator & & 54.38 & 45.62 & & & & \\
\hline Separate Toilet & & 13.13 & 86.87 & & & & \\
\hline No. of Observations & & & & & & & 1,120 \\
\hline
\end{tabular}


Table 15: Differences in Weekly Rent Offers between Periods

\begin{tabular}{|c|c|c|}
\hline \multicolumn{3}{|c|}{ Total number of new ads per week } \\
\hline PRE - POST & 352.28 & $* * *$ \\
\hline TRANS - POST & 338.70 & $* * *$ \\
\hline PRE - TRANS & 13.58 & \\
\hline \multicolumn{3}{|c|}{...thereof in treatment group } \\
\hline PRE - POST & 286.04 & $* * *$ \\
\hline TRANS - POST & 285.14 & $* * *$ \\
\hline PRE - TRANS & 0.91 & \\
\hline \multicolumn{3}{|c|}{...thereof in control group } \\
\hline $\mathrm{PRE}-\mathrm{POST}$ & 66.24 & $* * *$ \\
\hline TRANS - POST & 53.56 & $* * *$ \\
\hline PRE - TRANS & 12.68 & $*$ \\
\hline \multicolumn{3}{|c|}{ POST period 2018, 2019, 2020 } \\
\hline $2018-2019$ & -53.24 & . \\
\hline $2018-2020$ & 321.90 & $* * *$ \\
\hline $2019-2020$ & 375.13 & $* * *$ \\
\hline
\end{tabular}

Notes: The Tukey post-hoc test indicates significance of the differences in mean values using standard notation: · p-value $<0.1 ;{ }^{*}$-value $<0.05 ;{ }^{* *}$-value $<0.01,{ }^{* * *}$ p-value $<0.001$. 


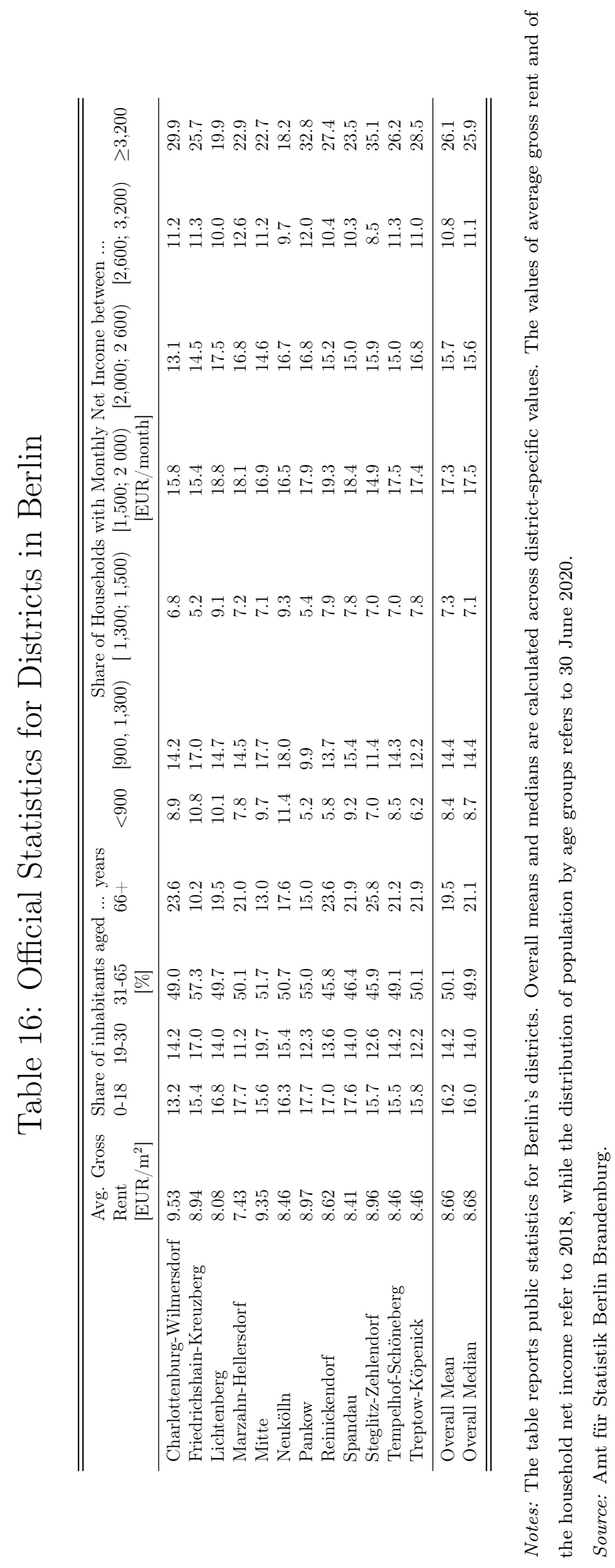

